\title{
Sedimentation of long-lasting wind-affected volcanic plumes: the example of the 2011 rhyolitic Cordón Caulle eruption, Chile
}

\author{
Costanza Bonadonna - Raffaello Cioni - Marco Pistolesi • \\ Manuela Elissondo • Valerie Baumann
}

Received: 17 July 2014 / Accepted: 8 January 2015 / Published online: 30 January 2015

(C) Springer-Verlag Berlin Heidelberg 2015

\begin{abstract}
Sedimentation processes and fragmentation mechanisms during explosive volcanic eruptions can be constrained based on detailed analysis of grain-size variations of tephra deposits with distance from vent and total grain-size distribution (TGSD). Grain-size studies strongly rely on deposit exposure and, in case of long-lasting eruptions, can be complicated by the intricate interplay between eruptive style, atmospheric conditions, particle accumulation, and deposit erosion. The 2011 Cordón Caulle eruption, Chile, represents an ideals laboratory for the study of long-lasting eruptions thanks to the good deposit accessibility in medial to distal area. All layers analyzed are mostly characterized by bimodal grain-size distributions, with both the modes and the fraction of the coarse subpopulation decreasing rapidly with distance from vent and those of the fine subpopulation being mostly stable. Due to gradually changing wind direction, the two subpopulations characterizing the deposit of the first 2 days of the eruption are asymmetrically distributed with respect to the dispersal axis. The TGSD of the climactic phase is also bimodal, with the coarse subpopulation representing $90 \mathrm{wt} \%$ of the whole distribution. Polymodality of individual samples is related to size-selective sedimentation processes, while polymodality of the TGSD is mostly related to the complex internal texture (e.g., size and shape of vesicles) of the most abundant juvenile
\end{abstract}

Editorial responsibility: V. Manville

C. Bonadonna $(\bowtie)$

Section des sciences de la Terre et de l'environnement, Universitè de Genève, Geneva, Switzerland

e-mail: Costanza.Bonadonna@unige.ch

R. Cioni $\cdot$ M. Pistolesi

Dipartimento di Scienze della Terra, Università di Firenze,

Florence, Italy

M. Elissondo $\cdot$ V. Baumann

Servicio Geológico Minero Argentino, Buenos Aires, Argentina clasts. The most representative TGSD could be derived based on a combination of the Voronoi tessellation with a detailed analysis of the thinning trend of individual size categories. Finally, preferential breakage of coarse pumices on ground impact was inferred from the study of particle terminal velocity.

Keywords Tephra $\cdot$ Particle aggregation $\cdot$ Grain-size bimodality $\cdot$ Total grain-size distribution $\cdot$ Particle terminal velocity $\cdot$ Inversion strategies

\section{Introduction}

Critical insights into eruption dynamics can be inferred from the study of the size of pyroclastic fragments, i.e., tephra (Kaminski and Jaupart 1998; Kueppers et al. 2006; Perugini et al. 2011; Rust and Cashman 2011; Dingwell et al. 2012). In addition, grain-size distributions and their variation with distance from vent can highlight important sedimentation processes that occurred during the eruption, e.g., particle aggregation and convective instabilities (Durant and Rose 2009; Durant et al. 2009; Brown et al. 2012; Carazzo and Jellinek 2012; Carazzo and Jellinek 2013). Finally, total grain-size distribution (TGSD) represents a critical source parameter in numerical models for the description of tephra transport and sedimentation, used to compile both long-term hazard assessments and real-time forecasts crucial to mitigation strategies of volcanic risk. An accurate description of the amount of fine particles has also significant implications for the assessment of specific tephra hazards (e.g., impact on human and animal health, long-range threat to aviation, long-term ash resuspension) (e.g., Durant and Rose 2009). Nonetheless, the determination of TGSD is not straightforward due to i) poor exposure 
of many tephra deposits, with very proximal and very distal areas being often of difficult access, ii) variable rate of deposit erosion, and iii) the complexity of integrating individual grain size samples to derive the TGSD of the whole deposit (Bonadonna and Houghton 2005). TGSD of long-lasting eruptions is even more complicated by the combination of multiple pulses that are often not easy to correlate in the field and which are possibly associated with different mechanisms of magma fragmentation and clast dispersal.

Only a few TGSDs are available in the literature, and those available often lack either the fine or the coarse fraction, or both, and often represent a combination of multiple pulses (e.g., Rotongaio Ash (Walker 1981); Askja 1875 (Sparks et al. 1981); Mt St Helens 1980 (Carey and Sigurdsson 1982; Durant et al. 2009); Fuego 1974 (Murrow et al. 1980; Rose et al. 2007); Etna 2001 (Scollo et al. 2007); Spurr 1992 (Durant and Rose 2009); Eyjafjallajökull 2010 (Bonadonna et al. 2011); Pululagua 2450BP (Volentik et al. 2010); 4-ka Rungwe Pumice (Fontijn et al. 2011)). Here, we investigate the grain size and sedimentological features of the 2011 Cordón Caulle long-lasting eruption and assess the uncertainties associated with the determination of the TGSD. A detailed characterization of the stratigraphy and deposit features is presented by Pistolesi et al. (2015).

\section{Stratigraphy and eruption evolution}

After about 41 years of repose, the Puyehue-Cordón Caulle volcanic complex (Central Andes) erupted on June 4, 2011, from a system of vents located about $1500 \mathrm{~m}$ above sea level (a.s.1.) on a NW-SE fracture of the Cordón Caulle system (Castro et al. 2013; Pistolesi et al. 2015). This resulted in the evacuation of ca. 4000 people in Chile and, due to the prevailing winds, widespread disruption to various economic sectors and human activities in Argentina (Collini et al. 2013; Wilson et al. 2013). The eruption developed as a long-lasting rhyolitic activity with plume heights above the vent between ca. 9 and $12 \mathrm{~km}$ above the vent during the first 3-4 days, 4 and $9 \mathrm{~km}$ during the following week, and $<6 \mathrm{~km}$ after 14 June (Global Volcanism Program, GVP, http://www.volcano.si.edu; Siebert et al. 2010). The whole Cordón Caulle eruption was strongly affected by wind, with only the first plume on June 4 being classified as subplinian (mass flow rate of the order of $\sim 10^{7} \mathrm{~kg} / \mathrm{s}$ ), with the rest of the eruption being smallmoderate with the cumulative volume of the first 3-4 days characterized by a volcanic explosivity index (VEI) of 5 (Bonadonna et al. 2015, in press). Thirteen tephra layers were identified, correlated, and organized into four units based on lithologic characteristics, grain size features, and discontinuity surfaces; satellite images were then used to correlate each unit with specific eruptive phases (Pistolesi et al. 2015).
Unit I (layers A to F) is a white to yellow lapilli-bearing deposit that represents the coarsest unit of the whole eruption (with $\mathrm{B}, \mathrm{D}$, and $\mathrm{F}$ being the coarsest layers). It was deposited towards the east-southeast on June 4 to 5 with negligible upwind sedimentation. The six layers are characterized by a distinct, multiple reverse grading and separated by planar discontinuities only evident in proximal-to-medial areas $(<50 \mathrm{~km}$ from vent) mainly marked by sharp grain-size changes. Farther from vent $(25-50 \mathrm{~km})$, separation between the six layers becomes difficult to observe, and the deposit grades into a single, thin $(<10 \mathrm{~cm})$, massive, fine lapilli to coarse ash bed. The second eruptive phase (June 5-6; unit II with layers $\mathrm{G}$ and $\mathrm{H}$ ) was marked by multiple wind shifts depositing the obsidian-rich layer $\mathrm{G}$ towards the north and the distinctive light orange-brown, pumice-rich layer $\mathrm{H}$ towards the east. Layer $\mathrm{H}$ was used as a marker to separate units I and II from unit III. The third phase started on the morning of June 7 depositing gray ash to light-gray fine lapilli-bearing layers K1 to K5 towards the east (unit III). This phase was also associated with the emission of large ballistic bombs in the proximal area (Castro et al. 2013; Pistolesi et al. 2015). The fourth phase (unit IV) deposited a thin layer of white fine ash around the eruptive vent up to the southern slopes of Puyehue volcano (i.e., $15 \mathrm{~km}$ from Cordón Caulle). No accurate time constraint could be made for the fourth phase based on the deposit. Tephra is characterized by the abundance of highly to extremely vesicular white pumice clasts, with minor banded and dense juvenile fragments, which largely increase after the first phase (unit I); lithic clasts are present within unit I and virtually absent in the following units. After the first three phases, emission of low-intensity eruptive plumes, mainly dispersing ash, characterized the eruption. However, more intense pulses of ash emissions were observed in July, October, and November 2011 and January 2012, which still caused disruption to aviation (Collini et al. 2013).

\section{Methodology}

The tephra deposit associated with the 2011 Cordón Caulle eruption was studied based on ca. 70 outcrops located between 1 and $240 \mathrm{~km}$ from the active vent (see Pistolesi et al. (2015) for more details). Isopach maps for layers A-B, A-F, $\mathrm{H}$, and $\mathrm{K} 2$ were converted into isomass maps based on mean values of deposit density, i.e., $560 \mathrm{~kg} \mathrm{~m}^{-3}$ for A-B and A-F and $600 \mathrm{~kg} \mathrm{~m}^{-3}$ for $\mathrm{H}$ and $\mathrm{K} 2$ (Fig. 1) (see Pistolesi et al. (2015) for details on isopach maps). Selected samples of layers $\mathrm{A}-\mathrm{B}, \mathrm{A}-\mathrm{F}, \mathrm{H}$, and $\mathrm{K} 2$ were dried and weighed in the $\mathrm{lab}$ and their volume was measured with a graduated cylinder in order to calculate the deposit density. Samples collected for grain-size analysis were dried and mechanically dry-sieved at half- $\phi$ intervals down to $0.5 \mathrm{~mm}\left(\phi=-\log _{2} D\right.$, where $D$ is the particle diameter in millimeters); the fine fraction $(<0.5 \mathrm{~mm})$ 

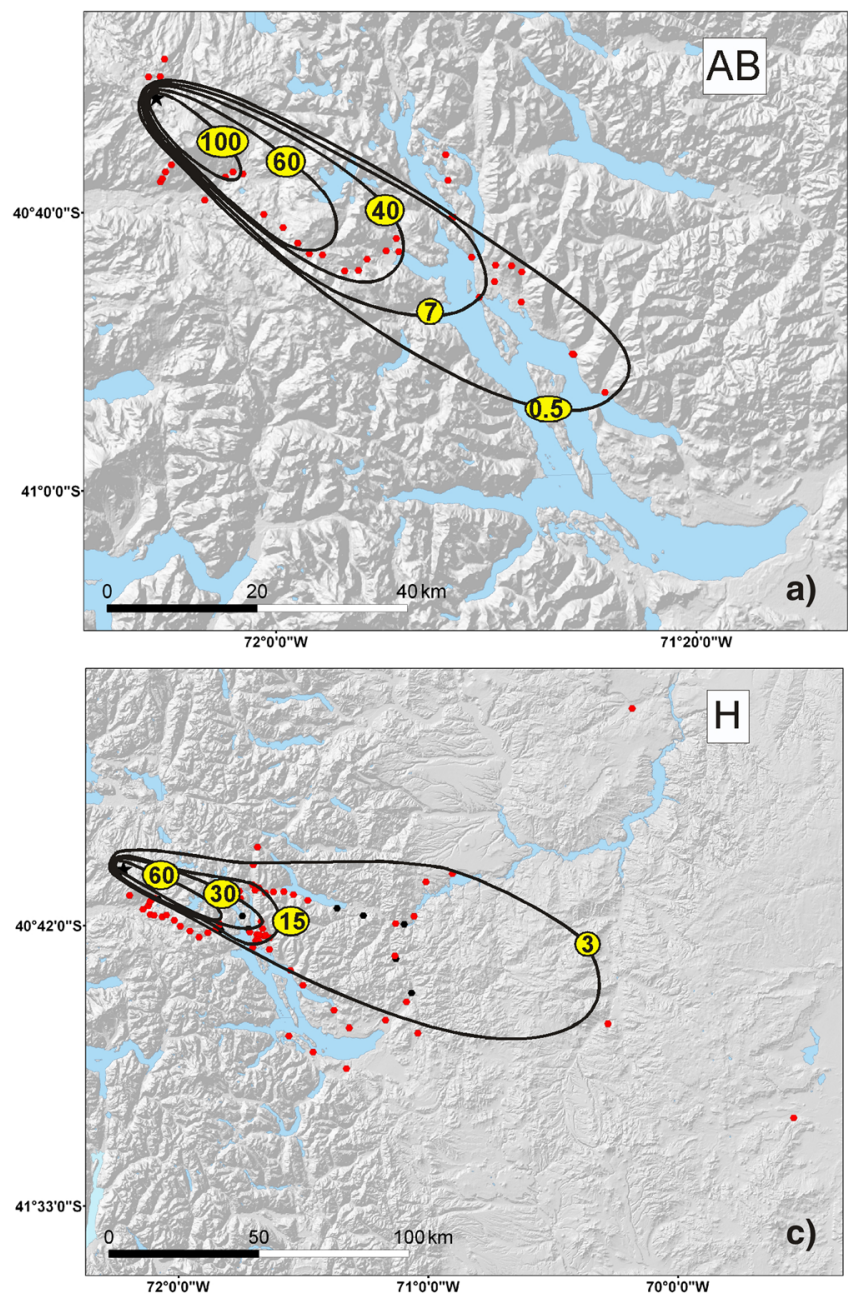

Fig. 1 Isomass maps (in $\mathrm{kg} \mathrm{m}^{-2}$ ) for a cumulative layer A-B; $\mathbf{b}$ unit I (cumulative layer A-F); c layer H; d layer K2. Black points indicate locations selected for grain size analysis. Thickness of individual

was characterized using a CILAS 1180 laser particle size analyzer. The combination of sieving and laser diffraction data was validated on selected samples by overlapping data resulting from the two techniques for the fractions between 0.5 and $0.063 \mathrm{~mm} . \operatorname{Md} \phi$ and $\sigma_{\phi}$ (sorting) values were calculated according to Inman (1952). One hundred ten grain size analyses of selected layers of units I, II, and III were carried out. However, given that the single layers forming unit I (A-F) were only distinguishable within $50 \mathrm{~km}$ from the vent, grain size analyses of proximal outcrops were obtained based on the thickness and density of each layer in order to obtain a cumulative A-F grain size distribution and investigate variations with distance from vent. Maps of lapilli fraction, coarse ash fraction, and fine-ash fraction and of individual $\phi$ categories of the cumulative unit I (layers A-F) were then compiled (Fig. 2 and Appendix 1). Grain-size analyses were also treated with the sequential fragmentation transport (SFT; (Wohletz et al. 1989)) software to investigate single subpopulations. For almost all the analyzed samples, two main subpopulations were
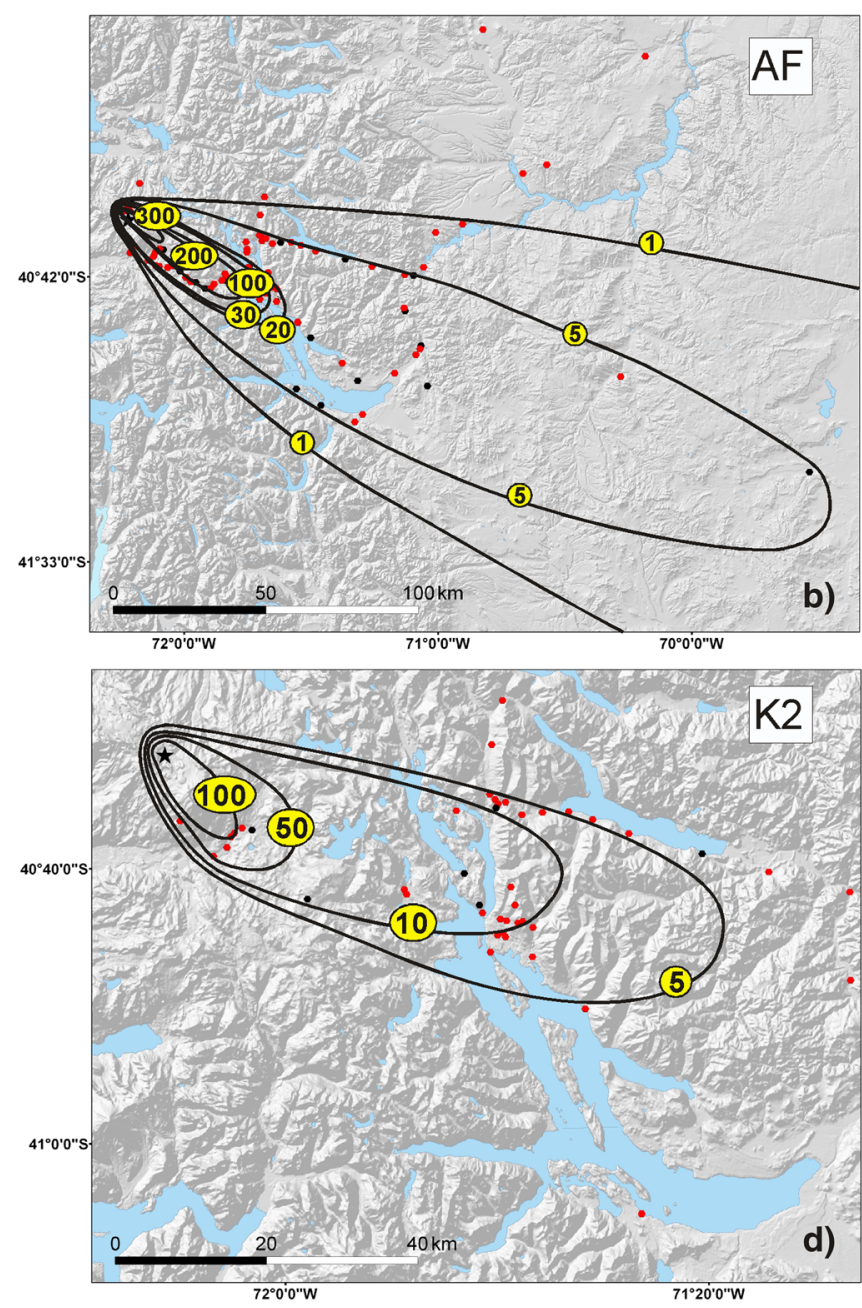

locations is reported in Pistolesi et al. (2015) and was converted into mass/area values based on deposit density (see text for details)

identified, here indicated as subpopulation 1 (SP1; coarse grained) and subpopulation 2 (SP2; fine grained), respectively. Componentry data, juvenile density, morphological and textural analysis, vesicularity, and chemistry are reported and discussed in detail by Pistolesi et al. (2015).

\section{Variations of grain size with distance from vent}

In agreement with the isomass maps of the whole deposit (Fig. 1), a strong elongation along the main wind direction is also shown by the isomass maps of individual size classes, accompanied by a substantial lack of upwind sedimentation (Fig. 2 and Appendix 1). Values of mass/area of unit I are plotted on a $\log$ axis versus distance from vent, instead of square root of contour area, in order to investigate better sedimentation trends and allow comparison with another deposit produced by a bent-over plume, i.e., the 1996 Ruapehu eruption, New Zealand (Bonadonna et al. 2005) (Fig. 3); the 

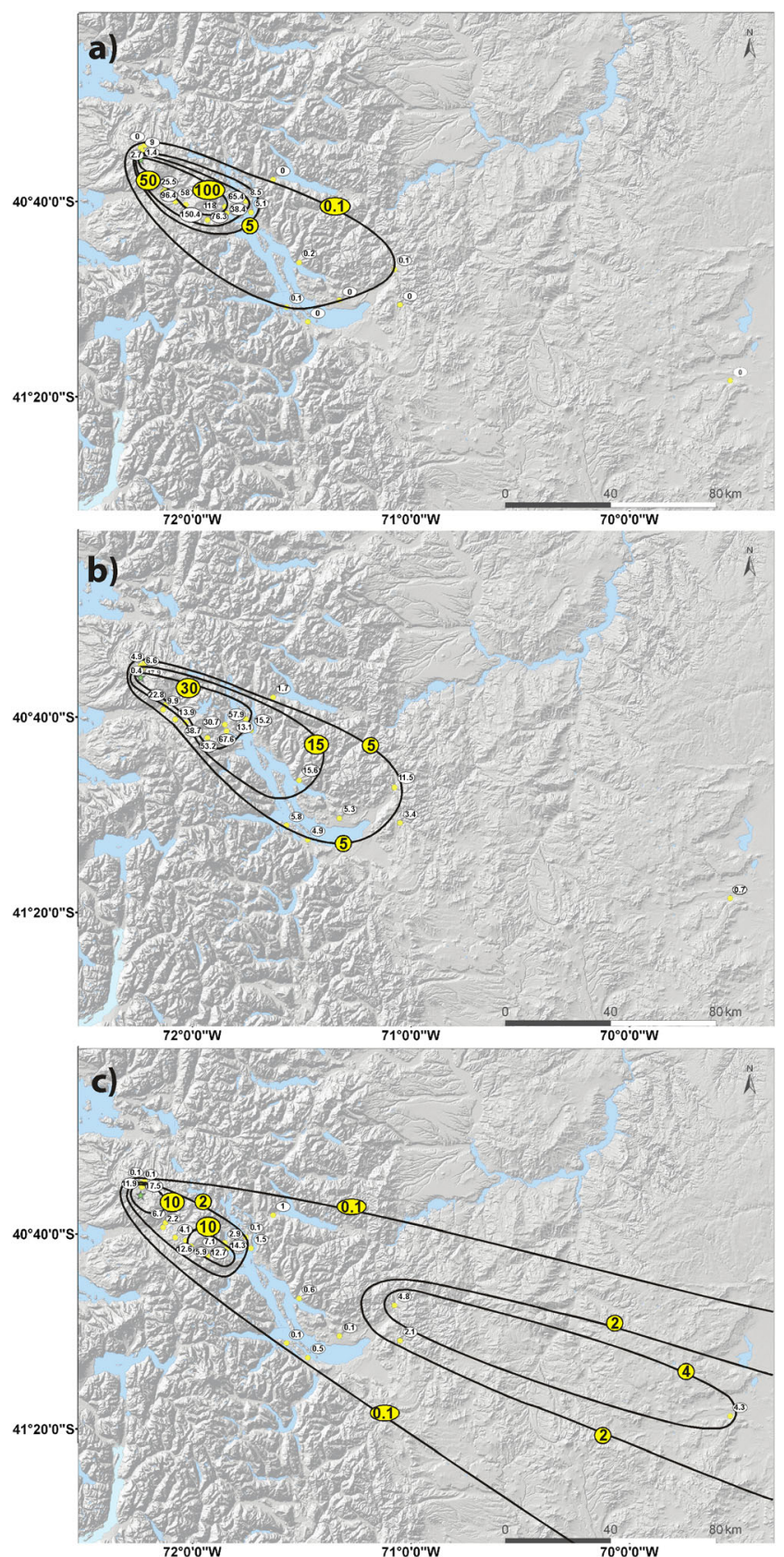

Fig. 2 Isomass maps (in $\mathrm{kg} \mathrm{m}^{-2}$ ) for unit I (cumulative layer A-F) of a lapilli clasts $(2-64 \mathrm{~mm} ; \leq-1 \phi)$; b coarse ash $(0.063-2 \mathrm{~mm} ; 0-4 \phi)$; $\mathbf{c}$ fine ash $(<0.063 \mathrm{~mm} ; \geq 5 \phi)$

detailed comparison is presented in the "Discussion" section. Lapilli clasts (diameter between 2 and $64 \mathrm{~mm}$ ) are dispersed within the first $90 \mathrm{~km}$ from the vent with a load of more than $100 \mathrm{~kg} \mathrm{~m}^{-2}$ within the first $40 \mathrm{~km}$ (Figs. 2a and 3a). The maximum accumulation of coarse ash is less significant than for the lapilli clasts, being just over $30 \mathrm{~kg} \mathrm{~m}^{-2}$ within the first $45 \mathrm{~km}$ and decreasing to $5 \mathrm{~kg} \mathrm{~m}^{-2}$ around $110 \mathrm{~km}$ from vent (Figs. $2 \mathrm{~b}$ and $3 \mathrm{a}$ ). Fine ash represents the predominant size fraction beyond $100 \mathrm{~km}$ from vent (see for example the maps of lapilli and coarse ash; Figs. 2 and 3a). Isomass maps of
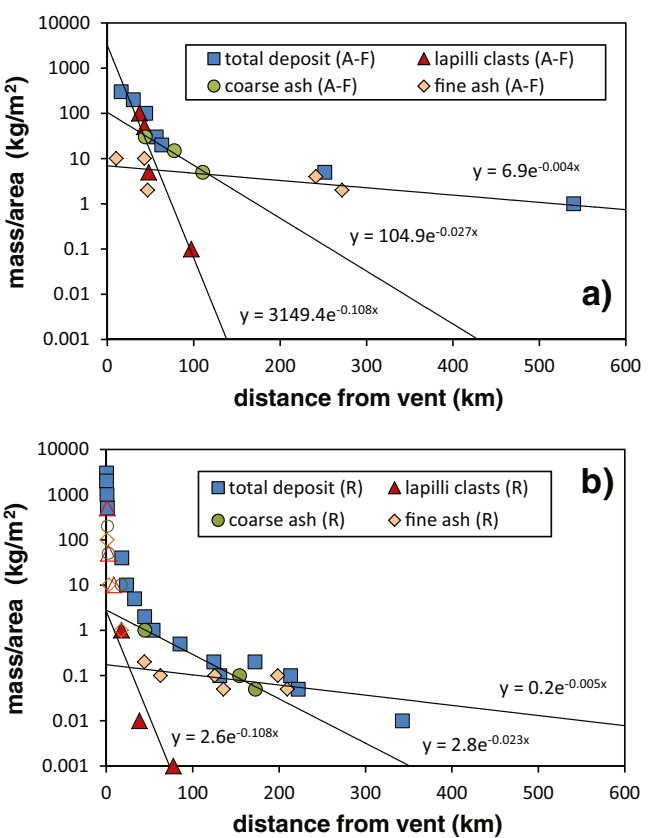

Fig. 3 Semi-log plot showing the variation of mass/area $\left(\mathrm{kg} \mathrm{m}^{-2}\right)$ versus distance from vent $(\mathrm{km})$ of total deposit, lapilli clasts, coarse ash, and fine ash for a unit I (layers A-F) (data from Figs. 1 and 2). Double maxima are evident for the fine ash fraction (i.e., 2 and $10 \mathrm{~kg} \mathrm{~m}^{-2}$ ); $\mathbf{b}$ the tephra deposit associated with the 1996 eruption of Ruapehu (data from Bonadonna et al. 2005). Double maxima are evident for the fine ash fraction (i.e. 0.05 and $0.1 \mathrm{~kg} \mathrm{~m}^{-2}$ ) and the total deposit (i.e., 0.1 and $0.2 \mathrm{~kg} \mathrm{~m}^{-2}$ ). Best-fit equations are also shown for the three size fractions. For the Ruapehu deposit, the best-fit was determined only for the most distal segment of each component indicated by solid symbols (empty symbols indicating the whole trend are also shown for completeness)

individual $\phi$ categories confirm that the low abundance of coarse ash is mainly related to the scarce sedimentation of particles in the $3 \phi$ class $(250-125 \mu \mathrm{m})$, while ash in the categories $4 \phi$ and $\geq 5 \phi$ categories (between $63-125$ and $<63 \mu \mathrm{m}$ ) clearly extends beyond $250 \mathrm{~km}$ from vent (Appendix 1). Multiple accumulation maxima are clearly visible only in the fine ash map, with the two most significant being located around 20 and $100 \mathrm{~km}$ from vent. However, these multiple maxima are not visible in the total deposit map (Figs 2c and 3a).

Detailed analyses of individual samples highlight a rapid decay of mean grain size for all layers from proximal $(\mathrm{Md} \phi=$ $-3.5,-1.6$, and -0.8 for $\mathrm{A}-\mathrm{F}, \mathrm{K} 2$, and $\mathrm{H}$, respectively) to distal samples ( $\mathrm{Md} \phi=5$ for $\mathrm{A}-\mathrm{F}$ and $\mathrm{K} 2)$, followed by a less steep decrease between 50 and $250 \mathrm{~km}$ (Fig. 4a). Between 50 and $120 \mathrm{~km}$ from vent, $\mathrm{Md} \phi$ values range between 0.5 and 5.2 for A-F and $\mathrm{K} 2$ and between 4.8 and 5.2 for $\mathrm{H}$, reaching 5.4 at our most distal sample of A-F and K2 (i.e., $240 \mathrm{~km}$ from the vent) (Fig. 4a). Sorting does not show any clear trend with distance from vent, varying between 0.3 and 2.9 for A-F (very well sorted to poorly sorted), 0.7 and 2.4 for $\mathrm{H}$ (very well sorted to poorly sorted), and 1.2 and 3.3 for K2 (well sorted to poorly sorted) (Fig. 4b). Many of these values stay at the upper limit of the fallout field of the $\operatorname{Md} \phi-\sigma \phi$ of Fisher and 

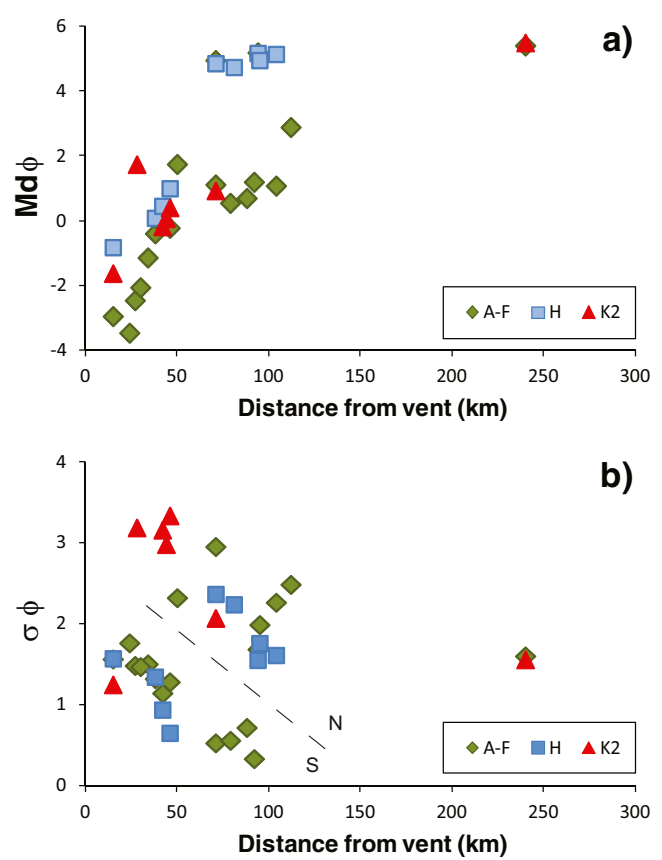

Fig. 4 Variations with distance from vent of a mean $(\mathrm{Md} \phi)$ values and $\mathbf{b}$ sorting $(\sigma \phi)$ values of layers A-F, H, and K2. Dashed line separates the samples of A-F and $\mathrm{H}$ collected north $(N)$ and south $(S)$ of the dispersal axis. K2 samples follow a more irregular trend (see text for more details)

Schmincke (1984). A detailed analysis of the sorting data shows how the best sorted samples (mostly for A-F and $\mathrm{H}$ ) are those associated with the deposit south of the dispersal axis (Fig. 4b). Due to a clear increase of particle density with the decrease of particle size (Pistolesi et al. 2015), the increase of the $\operatorname{Md} \phi$ value with distance from vent is the main cause for the increase of deposit density (Fig. 5). In fact, deposit density varies between 330 and $920 \mathrm{~kg} \mathrm{~m}^{-3}$ between about 24 and $240 \mathrm{~km}$ from vent. However, the most rapid change (from 330 to $790 \mathrm{~kg} \mathrm{~m}^{-3}$ ) is observed between 24 and $50 \mathrm{~km}$ from vent, where $\operatorname{Md} \phi$ has the largest variability (Figs. $4 \mathrm{a}$ and 5). The correlation of deposit density with $\mathrm{Md} \phi$ is remarkably linear (i.e., exponential with the representative particle diameter in $\mathrm{mm})$ (Fig. 5b).

Most of the sampled deposits (A-F, H, and K2), with the exception of our most distal sample at $240 \mathrm{~km}$ from vent, are characterized by a clear grain-size bimodality, which can be deconvoluted into two main Gaussian subpopulations (SP1 and SP2) using the SFT software (Fig. 6). The weight fraction associated with the coarse subpopulation (SP1) is $>75 \%$ for most samples south of the dispersal axis (Fig. 6a), which are also characterized by the best sorting (Fig. $4 \mathrm{~b}$ ). The mode of SP1 decreases with distance from the vent from -2.6 to $1.8 \phi$ (between 15 and $100 \mathrm{~km}$ from vent), and within the first $100 \mathrm{~km}$, it mostly coincides with $\operatorname{Md} \phi$ values of the whole samples (Figs. $4 \mathrm{a}$ and $6 \mathrm{~b}$ ). The decay trend of SP1 is similar for all layers, with $\mathrm{A}-\mathrm{F}$ being typically the coarsest and $\mathrm{H}$ the finest through the whole deposit (Fig. 6b). The mass loading of SP1 of all layers decreases regularly with distance from vent,
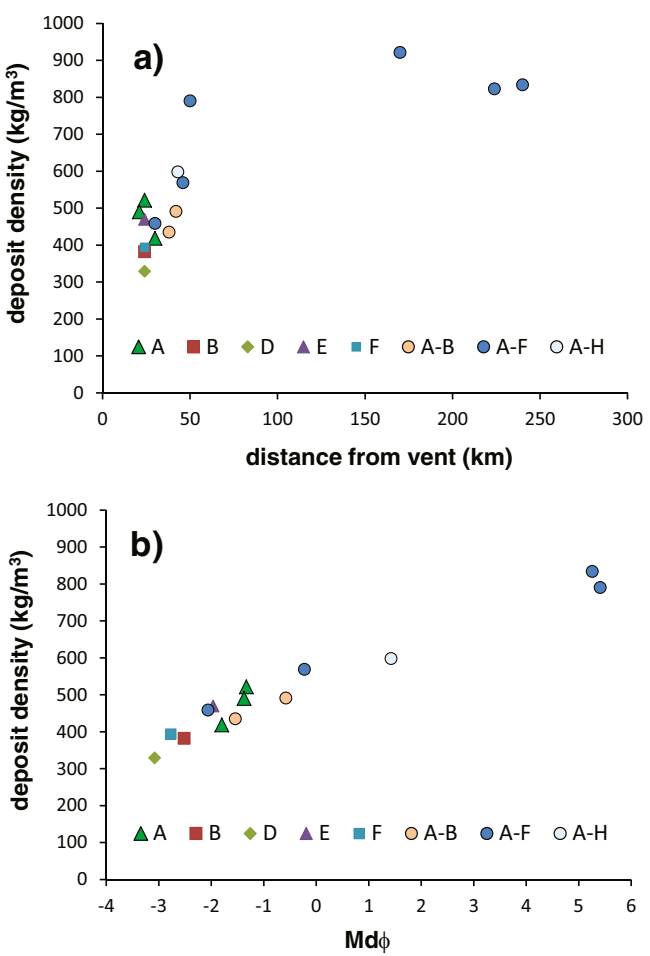

Fig. 5 Plot showing the variation of deposit density $\left(\mathrm{kg} \mathrm{m}^{-3}\right)$ of selected layers $\mathrm{A}$ to $\mathrm{H}$ with $\mathbf{a}$ distance from vent $(\mathrm{km})$ and $\mathbf{b} \mathrm{Md} \phi$

going from about 455,38 , and $84 \mathrm{~kg} \mathrm{~m}^{-2}$ at $15-20 \mathrm{~km}$ from vent (for A-F, $\mathrm{H}$, and $\mathrm{K} 2$, respectively) to $<10 \mathrm{~kg} \mathrm{~m}^{-2}$ beyond about $80 \mathrm{~km}$ from vent for all layers and even to $<0.1 \mathrm{~kg} \mathrm{~m}^{-2}$ for layer $\mathrm{H}$ (Fig. 7a). In contrast, the mode of the fine-grained
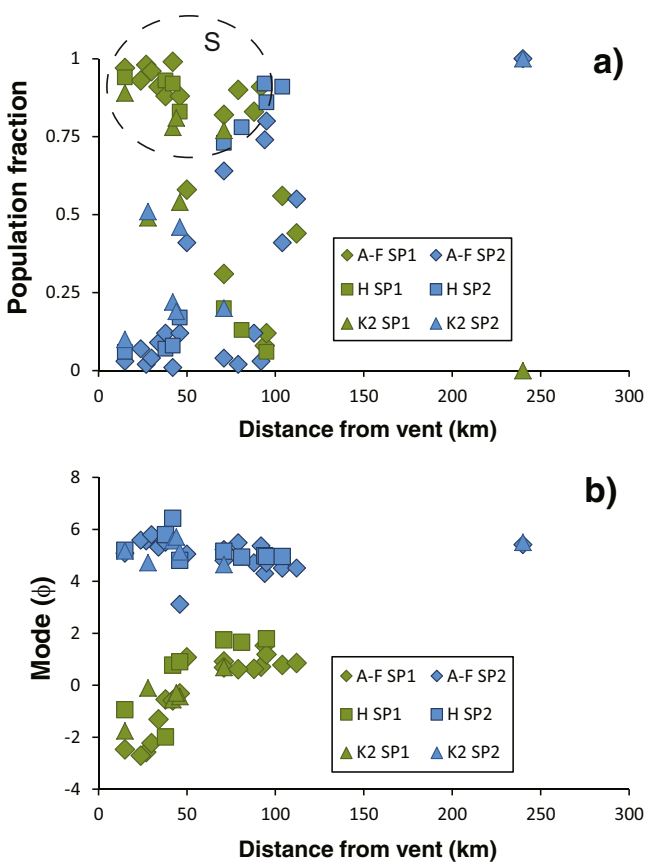

Fig. 6 Variation with distance from vent of $\mathbf{a}$ the fraction and $\mathbf{b}$ the mode of the two main subpopulations (SP1 and SP2) for layers A-F, $\mathrm{H}$, and K2. Dashed black ellipse indicates samples collected south $(S)$ of the dispersal axis 

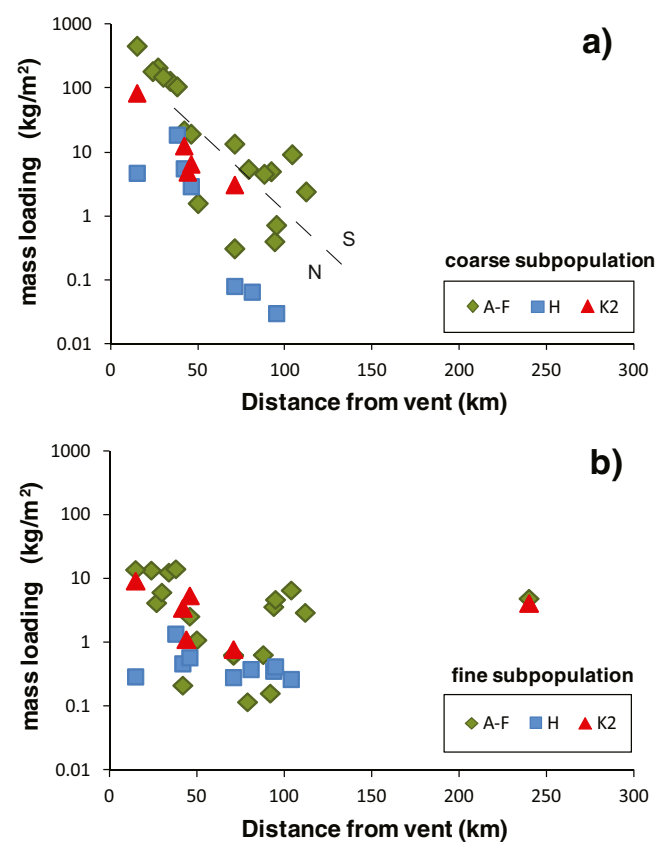

Fig. 7 Semi-log plots showing the variation with distance from vent of the mass load of $\mathbf{a}$ the coarse and $\mathbf{b}$ the fine subpopulations for layers A-F, $\mathrm{H}$, and K2. Dashed line separates the samples collected north $(N)$ and south $(S)$ of the dispersal axis subpopulation (SP2) remains nearly constant between 4.5 and $5.9 \phi$ (Fig. 6b), while the decay of the mass loading is less regular than for SP1 and always remains between 0.1 and $15 \mathrm{~kg} \mathrm{~m}^{-2}$ (Fig. 7b). The samples with the highest mass loading for SP1 are those south of the dispersal axis (Fig. 7a). Layer H is characterized by the smallest SP2, which varies between 0.3 and $1.4 \mathrm{~kg} \mathrm{~m}^{-2}$ throughout the whole deposit (i.e., 15$104 \mathrm{~km}$ from vent; Fig. 7b). Nonetheless, beyond $50 \mathrm{~km}$ from the vent, SP2 of $\mathrm{H}$ samples is always more abundant $(0.3-$ $\left.0.6 \mathrm{~kg} \mathrm{~m}^{-2}\right)$ than the associated SP1 $\left(<0.1 \mathrm{~kg} \mathrm{~m}^{-2}\right)$.

Grain-size variations are asymmetrically distributed across the dispersal axis, the relative abundance of SP1 in the southern samples being larger than that of the northern samples (Fig. 8). This is particularly evident in samples from unit I (A-F layers) and can explain the poor correlation of $\sigma \phi$ with distance from vent (Fig. 4b), the relative amount of SP1 and SP2 (Fig. 6a), and the corresponding mass loadings (Fig. 7).

\section{Distribution of terminal velocity}

In order to investigate particle sedimentation, terminal velocity was determined for the coarse clasts $(-4.5$ to $0 \phi)$ that

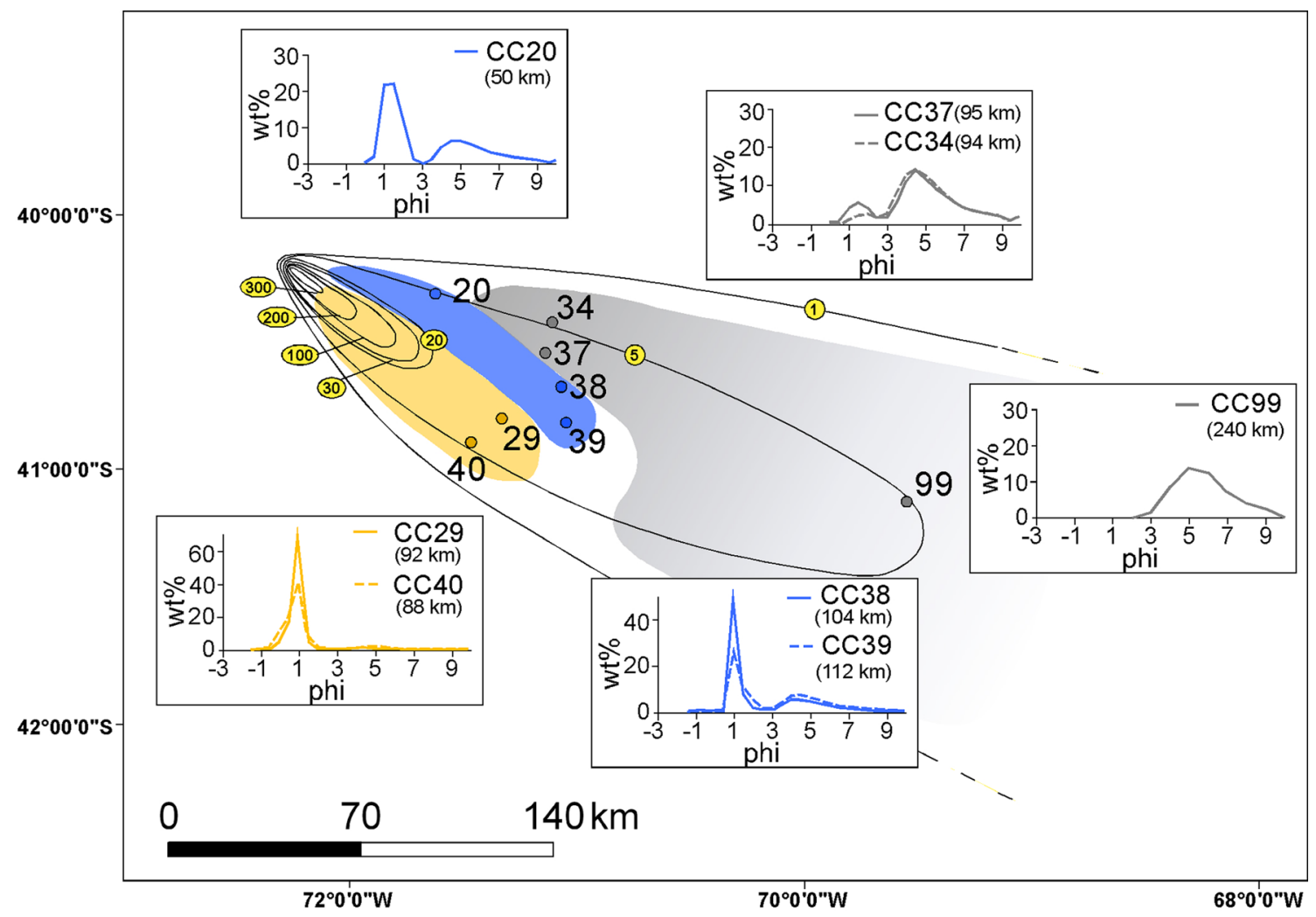

Fig. 8 Isomass map of A-F samples showing the spatial variation of grain-size features: the yellow zone is characterized by nearly unimodal samples mostly represented by SP1 (e.g., CC29, CC40), the blue zone is mostly characterized by bimodal samples with a predominance of SP1 (e.g., CC20, CC38, CC39), and the gray zone is mostly characterized by bimodal to unimodal samples with a predominance of SP2 (e.g., CC37, CC34, C99). Numbers in brackets indicate distance from vent 
fell at a locality $15 \mathrm{~km}$ downwind from the vent along the dispersal axis (Fig. 9 and Appendix 2). First, the clasts were grouped into two different density categories based on the detailed componentry and density analysis carried out by Pistolesi et al. (2015): a high constant density category and a variable size-dependent density category (for 4.5 to $0 \phi-435$ to $978 \mathrm{~kg} \mathrm{~m}^{-3}$, layers A to F, Fig. $9 \mathrm{~b} ; 440$ to $863 \mathrm{~kg} \mathrm{~m}^{-3}$, layer H, Fig. 9e; 460 to $1016 \mathrm{~kg} \mathrm{~m}^{-3}$, layer K2, Fig. 9h). The high-density category combines clasts with high constant density $\left(2700 \mathrm{~kg} \mathrm{~m}^{-3}\right)$, i.e., lithic and obsidian fragments, while the variable size-dependent density category consists of juvenile fragments with variable vesicularity, i.e., banded pumice clasts, dense juvenile clasts, and white pumice clasts (componentry classes defined as in Pistolesi et al. (2015)).

Clasts in the range $-4.5-0 \phi$ represent about $90 \mathrm{wt} \%$ of the deposit of all samples considered at this location, practically coinciding with SP1 (Fig. 9). Componentry plots also show that high-density clasts are most abundant within the finest size categories (i.e., 0 to $-3.5 \phi$ for $\mathrm{A}-\mathrm{F}$ and 0 to $-1.5 \phi$ for
$\mathrm{H}$ and $\mathrm{K} 2$ ), with the coarsest categories being mostly free of high-density clasts (i.e., -4.0 to $-4.5 \phi$ for $\mathrm{A}-\mathrm{F}$ and -2 to $-4 \phi$ for $\mathrm{H}$ and K2) (Fig. 9a, d, g and Appendix 2). Polymodality of the grain size distribution largely disappears when clast size is converted into terminal velocity, which peaks at a single value for all layers. The peak value mostly depends on plume height, i.e., $\sim 20 \mathrm{~m} / \mathrm{s}$ for $\mathrm{A}-\mathrm{F}, \sim 15 \mathrm{~m} / \mathrm{s}$ for $\mathrm{H}$, and $\sim 10-15 \mathrm{~m} / \mathrm{s} \mathrm{K} 2$ (maximum plume height of 14,12 , and $10 \mathrm{~km}$ for A to $\mathrm{F}, \mathrm{H}$, and $\mathrm{K} 2$, respectively).

It is also interesting to note how the spread of all velocity distributions is significantly narrower than that of grain size. When both high-density clasts and variable-density clasts are normalized to 100 and plot together, it is clear how, individually, they cannot always be described by a Gaussian distribution (Fig. 9c, f, i and Appendix 2). In addition, the two density categories overlap in the central velocity classes, whereas the highest and the lowest velocity classes are only represented by high-density and variable-density clasts, respectively, with mostly no overlap on the tails (bins of Fig. 9). In particular, the distribution of the variable-density clasts (i.e., juvenile
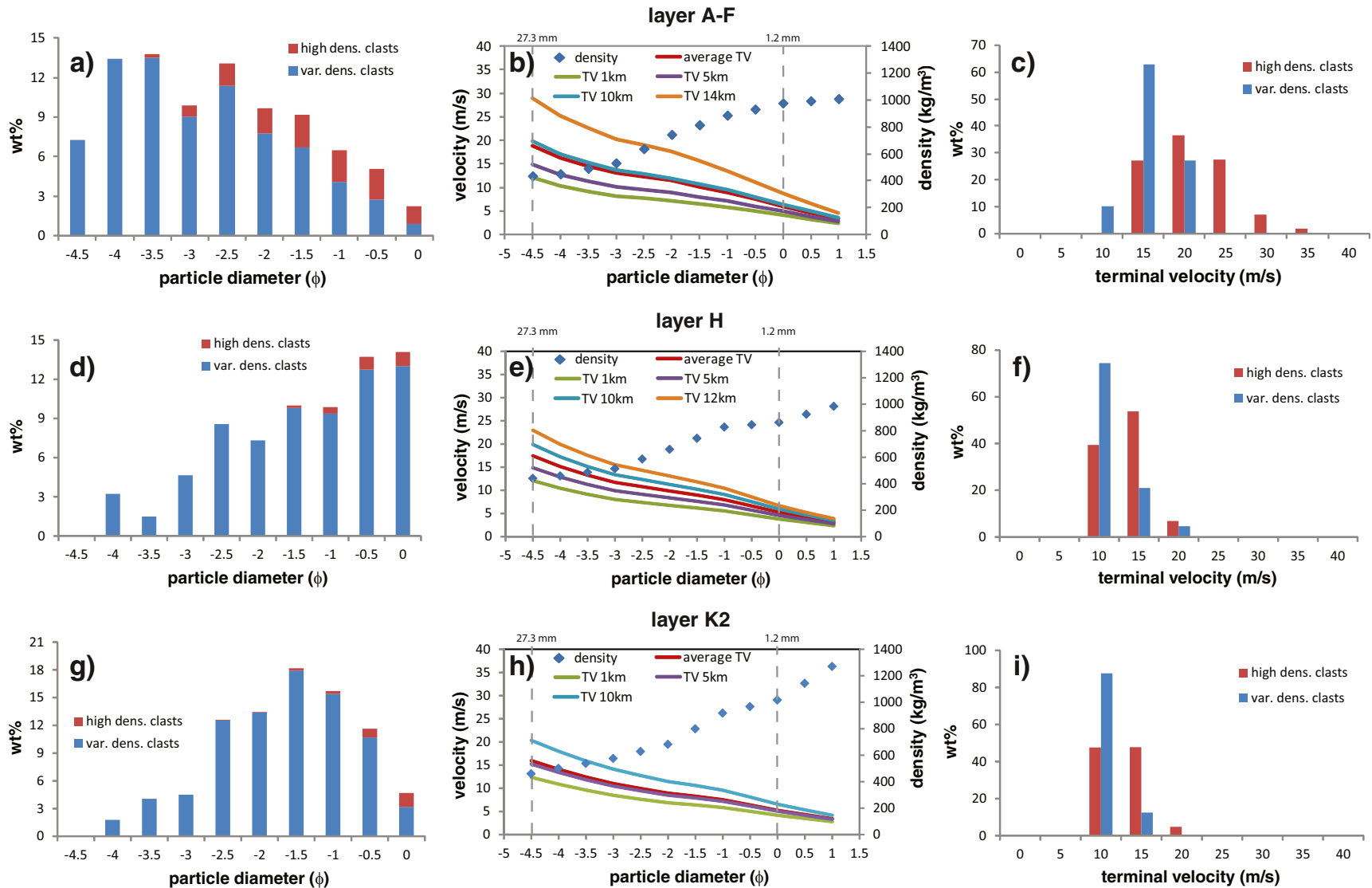

Fig. 9 a, d, and $\mathbf{g}$ Componentry (adjusted from Pistolesi et al. 2015); b, e, and $\mathbf{h}$ variation of terminal velocity $(T V)$ and density with particle diameter and height above sea level (density measured by Pistolesi et al. 2015); c, f, and $\mathbf{i}$ terminal velocity of tephra clasts ranging from 0 to $-4.5 \phi$ included (i.e., $1-32 \mathrm{~mm} ; \sim 90 \%$ of all deposit) for layers A-F, H, and $\mathrm{K} 2$ (normalized to $100 \mathrm{wt} \%$ for each category) at a locality about

$15 \mathrm{~km}$ from vent on the dispersal axis for unit I. For A-F, wt $\%$ of both componentry and terminal velocity were based on the weighted average of individual layers A to F. Correspondence between selected $\phi$ categories and particle diameter used to calculate terminal velocity is also shown. Please see main text and Appendix 2 for details on velocity calculation, clast categories, and the full set of plots for individual layers A to F 
vesicular clasts) seems to be shifted by about one bin category towards the low-velocity values (based on $5 \mathrm{~m} / \mathrm{s}$ binning; Figs. 9c, f, i and Appendix 2). This suggests an excess of clasts smaller than the modal size, probably related to clast breaking upon impact with ground. High-density clasts, less prone to break, do not show this feature, and their terminal velocity frequency distribution is generally much less peaked (more platykurtic) than that of variable-density clasts (Appendix 2). Based on the shift of the peak value of A-F from $20 \mathrm{~m} / \mathrm{s}$ (highdensity clasts) to $15 \mathrm{~m} / \mathrm{s}$ (variable-density clasts) (i.e., reduction of mean diameter value from $\sim 28$ to $\sim 13 \mathrm{~mm}$; Fig. 9), we can derive that the diameter of variable-density clasts was reduced by about $50 \%$ due to clast breakage. Breakage seems to be much more effective for large clasts, as evidenced by the general lack of variable-density clasts with high terminal velocity.

\section{Total grain size distribution}

The TGSD was determined for the climactic phase of the Cordón Caulle eruption based on different strategies: i) Voronoi tessellation (Bonadonna and Houghton 2005), ii) weighted average, and iii) mass of individual $\phi$ categories (Fig. 10 and Table 1). The mass of individual $\phi$ categories was derived in three different ways: (a) integration of the exponential and (b) Weibull fitting of the isomass maps of individual $\phi$ categories of Appendix 1 (Pyle 1989; Bonadonna and Costa 2012) and (c) inversion of values of mass/area of individual $\phi$ categories using the model TEPHRA2 following Volentik et al. (2010). Particles $<4 \phi$ were not considered in the last technique, as size-selective processes, such as particle aggregation and convective instabilities, cannot be currently described by inversion strategies (Fig. 10b and Appendix 4). The Voronoi tessellation was applied to two data sets: the complete data set of all our A-F samples (dataset 1) and the combination between dataset 1 and six additional distal points (around $610 \mathrm{~km}$ from vent) derived from two isopach maps compiled soon after the eruption that accounts for the distal deposit (dataset 2) (see Appendix 3 for details). We have assigned to these six distal points a grain size distribution based on the relative proportion of lapilli, coarse ash, and fine ash as derived from Fig. 3a. In fact, the best fit of the three size fractions considered indicates that around $610 \mathrm{~km}$ from vent, the deposit mostly consists of fine ash (see Appendix 3). Nonetheless, even if six distal samples are reconstructed and considered in the calculation, the resulting grain size does not change significantly (Fig. 10a and Table 1). Relative increase in fine ash for dataset 2 with respect to dataset 1 is $\sim 4 \mathrm{wt} \%$ (i.e., 13 and $9 \mathrm{wt} \%$, respectively; Table 1$)$. Not enough grain-size data were available to determine the TGSD of layers $\mathrm{H}$ and $\mathrm{K} 2$.

All strategies result in polymodal distributions with a clear lack of particles in the $3 \phi$ category, which is always $<1 \mathrm{wt} \%$. However, while the TGSD resulting from the Voronoi
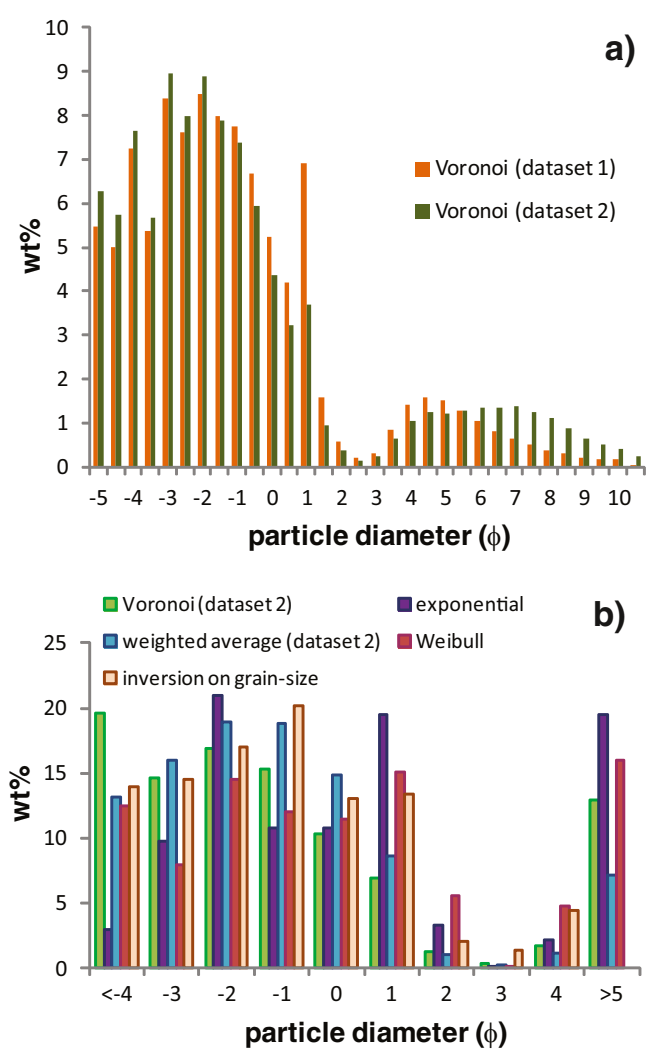

Fig. 10 Comparison of total grain-size distribution of unit I (cumulative layer A-F) determined based on a Voronoi tessellation applied on all sampled deposits (dataset 1) and on sample deposits combined with six reconstructed distal points (dataset 2) (see Appendix 4 for details) (half$\phi)$; b Voronoi (applied on dataset 2), weighted average (of dataset 2), and cumulative mass of individual $\phi$ categories (derived from exponential fit, Weibull fit, and inversion on grain size) (whole- $\phi$ ). See also Table 1 for associated grain size parameters

tessellation, weighted average, and inversion strategies are mostly bimodal with similar $\operatorname{Md} \phi$ and sorting values (Table 1), the TGSD derived from the mass associated with individual $\phi$ categories are more complex and polymodal, regardless of whether the associated mass is determined based on the exponential or the Weibull fitting. The TGSD derived with the Voronoi tessellation strategy is slightly coarser than the weighted average strategy because the Voronoi tessellation allows for a better representation of individual outcrops even when the distribution is not uniform, as is the case for the proximal samples from the Cordón Caulle eruption (e.g., Fig. 1). The TGSD derived with the inversion is also coarser, mostly because the fine ash fraction could not be considered in the calculation (i.e., particle $<4 \phi$ ). In all cases, TGSD shows two main subpopulations. The modal value of the coarse subpopulation is consistent for all datasets and strategies, with the exception of the exponential and Weibull integrations (i.e., -1.9 to $-2.5 \phi$; Table 1 ).

The advantage of the inversion on grain size with respect to the inversion on mass/area and the other strategies to derive TGSD is the derivation of the plume height, which, in the case of the climactic phase of the Córdon Caulle eruption, resulted in 
Table 1 TGSD grain size parameters as derived with different strategies and for different datasets (see text for more details)

\begin{tabular}{|c|c|c|c|c|c|c|c|}
\hline & Voronoi (DS1) & Voronoi (DS2) & $\begin{array}{l}\text { Weighted } \\
\text { average (DS1) }\end{array}$ & $\begin{array}{l}\text { Weighted } \\
\text { average (DS2) }\end{array}$ & $\begin{array}{l}\text { Inversion on } \\
\text { grain size }\end{array}$ & $\begin{array}{l}\text { Exponential } \\
\text { fitting }\end{array}$ & $\begin{array}{l}\text { Weibull } \\
\text { fitting }\end{array}$ \\
\hline $\operatorname{Md} \phi$ & -1.9 & -2.1 & -1.9 & -1.9 & -1.8 & -0.5 & -0.7 \\
\hline$\sigma \phi$ & 2.4 & 2.7 & 2.0 & 2.0 & 2.1 & 3.5 & 3.8 \\
\hline wt $\%$ fine ash & 8.7 & 12.9 & 6.9 & 7.1 & $\mathrm{ND}$ & 19.5 & 16.0 \\
\hline Mode of SP1 & -2.2 & -2.5 & -2.1 & -2.1 & -1.9 & -1.4 & -1.5 \\
\hline Fraction of SP1 & 0.9 & 0.9 & 0.9 & 0.9 & 1.0 & 0.8 & 0.8 \\
\hline Mode of SP2 & 5.1 & 6.2 & 5.4 & 5.4 & ND & ND & ND \\
\hline Fraction of SP2 & 0.1 & 0.1 & 0.1 & 0.1 & ND & ND & ND \\
\hline
\end{tabular}

$\operatorname{Md} \phi$ and $\sigma \phi$ are from Inman (1952). DS1 and DS2 are dataset 1 and 2 in Appendix 3. SP1 and SP2 are coarse- and fine-grained subpopulations, respectively

$N D$ not derivable

an average best fit value of $\sim 14 \mathrm{~km}$ a.s.l. with most particles being released between $\sim 9$ and $10 \mathrm{~km}$ a.s.l., in agreement with observations (Appendix 4) (targeted inversion on mass/area resulted in average plume height of $\sim 13 \mathrm{~km}$ a.s.l.; Bonadonna et al. 2015, in press). However, the root square mean error (RSME) minima associated with the best-fit values of plume height for the climactic phase of the Córdon Caulle eruption are not as well constrained as when applied to plumes developing in almost no wind (e.g., Pululagua 2450 BP Plinian eruption, Ecuador (Volentik et al. 2010), 4-ka Rungwe Pumice Plinian eruption, Tanzania (Fontijn et al. 2011)). In fact, similarly to mass/area inversion (Bonadonna et al. 2015, in press), the erupted mass of individual size categories is better constrained than plume height (Appendix 4). This is probably due to the stronger influence of wind entrainment on the plume rise, which increases the complex interaction among input parameters.

\section{Discussion}

The 2011 Córdon Caulle eruption represents an ideal case study to investigate grain size and sedimentological features of longlasting eruptions and to assess the complexities and uncertainties associated with the determination of the associated TGSD.

\section{Particle sedimentation}

As shown by our study, grain-size features vary significantly based on distance from the vent, eruptive style, intensity, and atmospheric conditions (e.g., Figs. 3, 4, 5, 6, 7 and 8). Further complexities in sedimentation can be added by the presence of multiple subpopulations in the TGSD, as is the case for the climactic phase of the Cordón Caulle eruption. This has obvious implications on the long-term assessment of eruption impact, including impact on human and animal health, impact on vegetation, generation of secondary lahars, and ash resuspension. Grain-size variation and mass accumulation with distance from vent can also be significantly affected by specific sedimentation processes, such as particle aggregation and convective instabilities. In order to investigate the general trend of particle deposition, we compare the sedimentation of the Cordón Caulle Unit I (plume height of 11-14 km a.s.l. and average wind speed along plume rise of $\sim 20 \mathrm{~m} \mathrm{~s}^{-1}$; Bonadonna et al. 2015, in press) with the sedimentation from another eruption strongly affected by wind for which detailed grain size data are also available: the Ruapehu 1996 eruption, New Zealand (Fig. 3b).

The Ruapehu eruption was characterized by a smaller erupted mass, a slightly lower plume and a slightly higher wind speed than the climactic phase of the Cordón Caulle eruption (plume height of $8.5 \mathrm{~km}$ a.s.l. and average wind speed along plume rise of $\sim 24 \mathrm{~m} \mathrm{~s}^{-1}$; (Prata and Grant 2001; Bonadonna et al. 2005)). However, the three main size fractions show a very similar thinning trend (i.e., lapilli, coarse ash, and fine ash) (Fig. 3). In fact, even though the total A-F deposit can be fitted by at least two exponential segments on a semi-log plot of mass/area versus distance from vent, individual size fractions could be well fitted by single exponential segments with slopes that are similar to those of the Ruapehu deposits (slope values for Cordón Caulle/Ruapehu, -0.108/ -0.108 for lapilli clasts, $-0.027 /-0.023$ for coarse ash, $-0.004 /-0.005$ for fine ash; Fig. 3). Due to the presence of an active lava flow emplaced during the eruption that could not be crossed during the field surveys, we could not collect data in the proximal downwind sector of Cordón Caulle ( $<15 \mathrm{~km}$ from the vent), precluding the possibility to recognize the most proximal exponential segments that can be identified at Ruapehu (Fig. 3b). The most distal break-in-slope for both cumulative thinning trends is associated with the intersection between the coarse ash and the fine ash trends (i.e., 110 and $150 \mathrm{~km}$ from vent for Cordón Caulle unit I and Ruapehu, respectively; Fig. 3). Due to a smaller erupted mass $\left(5 \times 10^{9} \mathrm{~kg}\right)$, smaller accumulations are observed for Ruapehu at any distance from vent (Fig. 3b). In addition, probably due to the lower plume, sedimentation of lapilli clasts is mostly 
confined within the first $10 \mathrm{~km}$ for the Ruapehu deposit, which results in a different relative proportion of the size components at any distance from vent. As an example, the relative proportions of lapilli clasts, coarse ash, and fine ash at about $40 \mathrm{~km}$ from vent is 56,33 , and $11 \%$ for Cordón Caulle A-F and 1,83 , and $16 \%$ for Ruapehu (total accumulation being about 90 and $1 \mathrm{~kg} \mathrm{~m}^{-2}$ for the two deposits, respectively). Fine ash becomes dominant for both deposits beyond $200 \mathrm{~km}$ from vent with a similar decay.

The similar deposit features shown by the Cordón Caulle unit I and the Ruapehu eruptions suggest that sedimentation from bent-over plumes is associated with similar thinning decay with distance from vent, even though the accumulation at any distance from vent is directly proportional to the total erupted mass and the relative fractions of lapilli clasts, coarse ash, and fine ash, which might change depending on plume height (with higher plumes dispersing coarse particles further from vent). It is also important to bear in mind also that the Ruapehu eruption was mostly associated with a unimodal and coarser TGSD, and, therefore, the thinning trend of size fractions seems to be independent from source conditions. We stress how such a detailed analysis of the thinning trend of individual size categories can provide insights into the grain-size distribution of distal deposits (e.g., Fig. 3 and Appendix 3). As an example, such a critical analysis clearly shows how the deposit mostly consists of fine ash beyond $200 \mathrm{~km}$, where the coarse ash is only about $0.5 \mathrm{~kg} \mathrm{~m}^{-2}$ ( $15 \%$ of the total loading).

\section{Grain size bimodality}

The layers analyzed in detail, i.e., A-F (4-5 June), H (6 June), and K2 (7 June) were all mostly characterized by bimodal grain size distributions. Similarly, samples collected from the entire A-F sequence all have the same grain-size features, evidencing no significant changes through the sequence (Pistolesi et al. 2015). An interesting feature is the decrease in grain-size of the SP1 mode with distance from vent for all layers and the stable mode of SP2 around 4-6 $\phi$ (Fig. 5b), which has already been observed in other tephra deposits (e.g., Montserrat, West Indies; St Vincent, West Indies; El Chichon, Chile; Mt St Helens, USA; Mt Mazama, USA (Brazier et al. 1983; Varekamp et al. 1984; Bonadonna et al. 2002; Durant et al. 2009; Brown et al. 2012; Durant et al. 2012). However, a more interesting aspect is the poorly variable mass loading $\left(0.1-15 \mathrm{~kg} \mathrm{~m}^{-2}\right)$ of SP2 that does not show any obvious trend with distance from vent and with the mass loading of SP1 (Fig. 6b), although samples collected south of the dispersal axis generally have a lower mass loading with respect to samples from similar distances collected north of the axis. While the regular decrease of the SP1 mode with distance from vent suggests normal settling of individual clasts dominated by plume height and wind advection, the ubiquitous presence of a fine subpopulation with a constant grain size distribution is interpreted as an evidence of settling dominated by size-selective sedimentation processes (e.g., particle aggregation and/or convective instabilities) that may have affected particle fallout even $15 \mathrm{~km}$ from the vent.

Particle aggregates were only observed within the K1 deposit at a few sites close to Villa La Angostura (48 km from the vent) (i.e., millimetric structured accretionary pellets; Pistolesi et al. 2015), suggesting that fine ash mostly fell as very fragile aggregates whose structure was not preserved during impact with ground (Brown et al. 2012). Unfortunately, we could not sample the deposit in more proximal areas to verify if aggregation occurred at distances $<15 \mathrm{~km}$ and, if so, in which form. Premature fallout of fine particles can also be associated with convective instabilities often observed during sedimentation of small-moderate eruption plumes, which could also enhance particle aggregation due to the increased particle concentrations within the resulting fingers (Bonadonna et al. 2002; 2005; 2011; Carazzo and Jellinek 2013; Manzella et al. 2015). Convective instabilities are expected to have played an important role also during the Cordón Caulle eruption, even though no clear pictures of downwind sedimentation during the climactic phase of the first few days are available to confirm this hypothesis. Considering that A-F, H, and K2 layers were generated by plumes with different intensities, we conclude that aggregation and/or convective instabilities were persistent processes throughout the whole eruption, not significantly affected by small differences in plume height.

A persistent subpopulation of fine particles generating bimodal grain-size distribution has also sometimes been reported as being generated by co-pyroclastic density current (PDC) plumes (Carey and Sigurdsson 1982; Bonadonna et al. 2002; Eychenne et al. 2012). However, Cordón Caulle PDCs had runout distances too short (i.e., $\sim 10 \mathrm{~km}$ ) and possibly volumes too small (ca. $10 \%$ of A-F total deposit; Pistolesi et al. 2015) to disperse a significant amount of fine ash up to $100 \mathrm{~km}$ from vent where bimodality is still observed (Pistolesi et al. 2015). In addition, PDCs were only observed on 4,5 (with a runout of $\sim 10 \mathrm{~km}$; (SERNAGEOMIN/OVDAS 2011)), 8, and 14 June, whereas layers $\mathrm{H}$ and $\mathrm{K} 2$ also show bimodal distributions and they were produced on 6-7 June 2011. However, we do not exclude that part of the ash component in the proximal A-F deposit (generated on 4-5 June) could be a combination of coPDC and main plume fallout.

Finally, grain size bimodality also affects deposit sorting. In fact, sorting is typically improved by wind advection, with tephra deposits generated during low-wind conditions being usually poorly sorted. However, this is not the case for the Cordón Caulle eruption. As an example, the Pululagua 2450 BP Plinian eruption, Ecuador (Volentik et al. 2010) and the 4-ka Rungwe Pumice Plinian eruption, Tanzania (Fontijn et al. 2011) are characterized by sorting between 1.1-3.0 and 1.3-2.0, respectively, which are in the same range shown by layers A-F, H, and K2 (i.e. 0.3 and 2.9, 0.6 and 2.4, and 1.2 
and 3.3, respectively; Fig. 4b). For the two no-wind eruptions, sorting seems to improve with distance from vent (particularly for the Pululagua eruption) and the associated TGSD is mostly unimodal. Regardless of the strong wind advection, sorting at Cordón Caulle is not significantly better than for the Pululagua and Rungwe Pumice eruptions, most probably because of the bimodality of grain size distributions at all outcrops (e.g., Fig. 6).

The sorting of the deposits of the climactic phase of the Cordón Caulle eruption was shown to be worst north of the dispersal axis due to a strong asymmetry of the distribution of the two subpopulations SP1 and SP2 (Fig. 8). Such an asymmetry was also observed for the small-moderate Mt St Helens eruptions (USA) on May 25 through August 7, 1980, which was explained as mostly due to distribution-rotation of wind direction with altitude and variability in the duration, height, and qualitative density of eruption columns (Waitt et al. 1981). Similarly, the preferential accumulation of SP1 and SP2 south and north of the dispersal axis, respectively, can be related to the progressive wind shift towards the north that occurred at the end of June 5 associated with a lowering of the plume height (e.g., Bonadonna et al. 2015, in press; Pistolesi et al. 2015).

\section{Secondary maxima of accumulation}

Multiple maxima of accumulation are shown by the fine ash fraction of the A-F deposit of Cordón Caulle, but not by the total deposit (Figs. 2 and 3 and Appendix 1). Secondary maxima of accumulation of the total deposit have often been associated with particle aggregation (e.g., Mt St Helens 1980 (Carey and Sigurdsson 1982; Durant et al. 2009); Hudson 1991 (Scasso et al. 1994); Quizapu 1932 (Hildreth and Drake 1992)). Multiple maxima of accumulation were also observed in the fine ash fraction of the deposit associated with the Ruapehu 1996 plume, New Zealand, for which particle aggregation was not so evident in the deposit but that was also strongly distorted by wind advection (Bonadonna et al. 2005). However, in the Ruapehu case, these multiple maxima coincide with multiple maxima in the total deposit (Fig. 3b). Even though, both for the Cordón Caulle eruption and the Ruapehu eruption, aggregation processes were not evident in the associated deposit, secondary maxima of accumulation are clearly related to size-selective sedimentation processes that affect only particles $\leq 63 \mu \mathrm{m}$. These processes are most likely related to particle aggregation and convective instabilities even when field evidence is missing. As an example, particle aggregation has been shown to generate fragile clusters that easily break on impact with the ground (e.g., Brown et al. 2012). Finally, considering that tephra deposits are not always investigated based on isomass maps of individual grain size categories, we can conclude that the fine-ash fraction tends to produce secondary maxima of accumulation even when these are not shown by the total tephra deposit.
Total grain size distribution

Our results show how the Voronoi tessellation, weighted average, and inversion strategy give more consistent results for TGSD than the strategies based on the mass calculated from empirical fits (i.e., exponential and Weibull fits). This is due to the poor distribution of mass/area points for individual $\phi$ categories that result in isomass maps with mostly $\leq 3$ contours (Appendix 1). Four and five contours could be well identified only for -1 and $0 \phi$. The mass associated with $3 \phi$ had to be calculated with the method of Legros (2000) as only one contour could be drawn. The cumulative mass derived with the exponential and Weibull method is about 60 and $75 \%$, respectively, of the total mass derived from the isopach map of the cumulative deposit of Pistolesi et al. (2015) (i.e., $\sim 2.8$ and $3.7 \times 10^{11}$ versus $\sim 5 \times 10^{11} \mathrm{~kg}$ ). In addition, the Voronoi tessellation for the derivation of TGSD is preferred with respect to the weighted average because it can better characterize nonuniform point distributions (as shown by the higher sensitivity to the addition of six distal points; Fig. 10 and Table 1) and to the inversion of individual size categories because this cannot be applied to the fine ash fraction that is likely to be affected by size-selective sedimentation processes (e.g., particle aggregation). In addition, the application of inversion strategies to eruptions strongly affected by wind entrainment seems to be more complex than the application to strong plumes (see also Bonadonna et al. 2015, in press). The TGSD of the A-F deposit as derived with the Voronoi tessellation applied to the dataset 1 is clearly bimodal, with the two main subpopulations peaked at -2.5 and $6.2 \phi$, a large fraction of the coarse population $(90 \mathrm{wt} \%$ ) and a significant low cumulative $\mathrm{wt} \%(0.8)$ of particles between 0.250 and $0.125 \mathrm{~mm}$ (i.e., 2-3 $\phi$ ) (Table 1).

Polymodality of TGSD has already been observed for other tephra deposits (e.g., Montserrat Vulcanian and dome collapse explosions (Bonadonna et al. 2002); Mt St Helens 1980 (Carey and Sigurdsson 1982; Durant et al. 2009); Mt Spurr 1992 (Durant and Rose 2009); Tunguragua 2006 (Eychenne et al. 2012); El Chichon 1982 (Varekamp et al. 1984); Pinatubo 1991 (Wiesner et al. 2004); 1979 Soufriere St Vincent, Mazama 7000 a. (Brazier et al. 1983)), for which it could be explained as mainly due to the contribution of sedimentation from co-PDC plumes. However, as already mentioned above, we consider the contribution of co-PDC sedimentation to be very limited for the Cordón Caulle eruption. In addition, such a striking polymodality is in contrast, for example, with the TGSD of another rhyolitic Plinian eruption ( $\beta$ layer, Chaitén 2008 eruption, Chile; Mastin et al. (2013) which is characterized by one single population peaked around $6 \phi$, i.e., mostly coinciding with the fine population of the A-F deposit. Considering that both eruptions have been studied in detail and the TGSD has been integrated over a similar deposit extension (up to about 600-800 km from source) and with the same methodologies, we believe that 
the striking differences are related to the actual fragmentation of the erupted material. In particular, it is important to bear in mind that about $80 \mathrm{wt} \%$ of the $\beta$ layer of the 2008 Chaitén eruption consists of non-vesicular material and that the associated vesicular juveniles are characterized by a unimodal vesicle size distribution (Alfano et al. 2012). Fragmentation of such homogeneous pyroclastic material is more likely to result in one single population than the fragmentation of polycomponent material characterized by juveniles with complex vesicle textures, such as that of Cordón Caulle unit I (Pistolesi et al. 2015; Schipper et al. 2013). Given the abundance of white pumice clasts in the A-F cumulative layer of Cordón Caulle, we conclude that the grain size polymodality is mostly due to the associated complex texture. In fact, white pumice clasts are characterized by the coexistence of spherical and nearly isotropic vesicles together with vesicles with highly deformed and convoluted shapes (Pistolesi et al. 2015), which, when fragmented, are likely to result in multiple distinct peaks of particle sizes.

\section{Terminal velocity}

Our detailed analysis of terminal velocity at the reference outcrop $15 \mathrm{~km}$ from vent has shown how particles deposited at a given location are peaked around a characteristic velocity that mostly depends on plume height and particle density (Fig. 9 and Appendix 2; to note that maximum plume heights were considered for all calculations and therefore particle terminal velocities are to be considered as maximum values). However, high-density and variable-density particles show different modal values for terminal velocity, generally overlapping only in a few central velocity classes. We have interpreted such a shift of the moderately to highly vesicular, variable-density clasts towards the low velocity categories as due to an important effect of clast breakage on impact with the ground. Based on the shift of the peak velocity values, we estimated such a breakage to be about $50 \%$ of the original diameter of the variable-density clasts.

This has important implications both for the determination of the largest clasts and of the TGSD. In fact, our results clearly support the recommendation of the collection of largest lithics as supposed to largest pumices for the compilation of isopleth maps (Sparks et al. 1981; Bonadonna et al. 2013). In addition, given the absence of variable-density clast sizes corresponding to the largest velocities, and to the evident increment of clasts in the modal terminal velocity (evidenced by the frequency distribution of terminal velocities for these clasts, highly peaked on a modal class with terminal velocity values equal or slightly lower than those of lithic fragments), we suggest that the coarsest variable-density clasts are the most affected by breakage at impact.

Considering that tephra deposits of subplinian-Plinian eruptions are typically mostly composed of variable-density (juvenile) clasts (e.g., variable-density clasts of A-F are $\sim 73 \%$ of the total deposit; Fig. 9 and Appendix 2), we can also conclude that TGSD derived from tephra deposits are very likely to be shifted towards lower size values, with a possible general underestimation of the coarse clast contribution. Dufek et al. (2012) have already shown the relation between amount of fine ash and fragmentation depth due to collisional processes in the conduit. Here, we show how additional breakage of lapilli clasts can occur on ground impact, inducing a shift in the calculated TGSD. This has important implication for the associated discussion of magma fragmentation and simulations of particle dispersal.

\section{Deposit erosion and particle resuspension}

Long-lasting eruptions are characterized by a complex interplay between tephra accumulation and deposit erosion depending also on local soil and atmospheric conditions (e.g., rain, snow, wind, vegetation cover, soil moisture). As an example, due to persistent strong winds, significant resuspension of the distal part the Córdon Caulle deposit affected air quality and resulted in the closure of important airports even months after the beginning of the eruption (e.g., 14-18 October 2011 (Wilson et al. 2013; Folch et al. 2014)). These resuspension events have also been recognized in other ash-rich deposits (e.g., Katmai, USA (Hadley et al. 2004); Mount St Helens, USA (Hobbs et al. 1983); Hudson, Chile (Wilson et al. 2011); Montserrat, West Indies (Hincks et al. 2006); Eyjafjallajökull, Iceland (Leadbetter et al. 2012; Thorsteinsson et al. 2012)) and can be comparable to the dispersal of primary ash fallout in terms of dispersal area, with the potential to cause widespread impact on agriculture, aviation, livestock, and human health long after a volcanic eruption and far away from the original eruptive vent.

The source term necessary to model and forecast resuspension events can only be characterized by a detailed study of the tephra deposit that can be potentially remobilized by strong winds. Local grain size distribution is likely to be very different from the TGSD of the eruption and can only be constructed based on a selection of critical outcrops. As a result, detailed stratigraphic studies of tephra deposits and the physical characterization of eruptive parameters becomes the first step to develop effective mitigation strategies and land-use planning. Resuspension mostly affected layers K1-K5 (unit III) of the 2011 Córdon Caulle deposit, which are the only layers that were found remobilized during our last field survey (i.e., February 2013). In fact, comparison between observations made during the first surveys (i.e., July 2011 and OctoberNovember 2011) with observations made in May 2012 and February 2013 show that erosion did not affect layers A to H. In addition, Layers K1-K5 are mostly characterized by particles with diameter $<250 \mu \mathrm{m}$, which was considered by Folch et al. (2014) as a threshold for resuspension for the Córdon 
Caulle deposit. The total thickness of remobilized material was then $<0.5 \mathrm{~cm}$. In general, a thinning plot showing the trend of the fine-ash fraction (e.g., Fig. 3a) can be used to derive the approximate amount of material that can be remobilized at any given distance.

\section{Conclusions}

In this paper we focus on particle size and sedimentation processes during the first eruptive phases of the 2011 Cordón Caulle eruption (i.e., June 4-7, 2011). Based on our detailed field campaigns and analytical studies we can conclude that

1. All layers analyzed (i.e., cumulative layer A-F, H, and K2) are mostly characterized by bimodal grain-size distributions, with the mode of the coarse subpopulation (SP1) decreasing rapidly with distance from vent (from -2.6 to $1.8 \phi$ between 15 and $100 \mathrm{~km}$ from vent) and the associated mass fraction varying from about $500 \mathrm{~kg} \mathrm{~m}^{-2}$ (15 km from vent) to $<10 \mathrm{~kg} \mathrm{~m}^{-2}$ (beyond $100 \mathrm{~km}$ from vent). In contrast, the mode of the fine subpopulation (SP2) remains stable between 4.5 and $5.9 \phi$ with a mass loading always between 0.1 and $15 \mathrm{~kg} \mathrm{~m}^{-2}$.

2. The fine subpopulation has been interpreted as being mostly associated with size-selective sedimentation processes (e.g., particle aggregation, convective instabilities) confirmed by the presence of multiple accumulation maxima associated with the fine ash fraction (i.e., particles $<63 \mu \mathrm{m}$ ). Considering the similarity of grainsize features and trends for the three layers analyzed, patterns of fine ash sedimentation during the Cordón Caulle eruption can be interpreted as being independent of plume height and eruptive style.

3. The presence of multiple maxima of accumulation for the fine ash fraction but not shown by the total deposit suggests that size-selective sedimentary processes play an important role in most eruptions even when multiple maxima are not shown by the total deposit.

4. The coarse and fine subpopulations of the A-F layers are asymmetrically distributed with respect to the dispersal axis, with SP1 being more abundant in the southern samples. This is probably related to the progressive shift of the wind direction towards the north, which occurred at the end of the deposition of unit I associated with a lowering of plume height (June 5).

5. The rapid decrease of $\mathrm{Md} \phi$ within the first $50 \mathrm{~km}$ is associated with a rapid increase of deposit density from 330 to $790 \mathrm{~kg} \mathrm{~m}^{-3}$. The highest value of deposit density observed is $920 \mathrm{~kg} \mathrm{~m}^{-3}$ at $240 \mathrm{~km}$ from vent (A-F layers).
6. The combination of Voronoi tessellation with a detailed analysis of the thinning trend of individual size categories (e.g., lapilli clasts, coarse ash, and fine ash) was considered to provide the most representative TGSD of the climactic phase of the Cordón Caulle eruption, which is characterized by two main subpopulations peaked at -2.5 and $6.2 \phi$, with the coarse subpopulation representing about $90 \mathrm{wt} \%$ of the whole distribution.

7. Detailed investigations have shown that the grain-size bimodality is not related to the lack of distal samples but to a significant lack of particles in the $3 \phi$ category. The addition of distal samples (600 km from vent) only slightly increases $(<5 \mathrm{wt} \%)$ the amount of fine ash. We suggest that the shape of the TGSD records a primary fragmentation process possibly related to the complex textural features of the highly vesicular magma.

8. The derivation of TGSD based on weighted average and on the mass of individual size categories as derived from empirical fits and analytical inversions were of more difficult application and did not provide exhaustive results. The analytical inversion could provide important insights into plume height, but should be used with caution when applied to eruptions strongly affected by wind entrainment.

9. Bent-over plumes of both Cordón Caulle (June 4-5) 2011 and Ruapehu 1996 eruptions are characterized by similar sedimentation patterns, with thinning of lapilli, coarse ash, and fine ash being described by exponential segments with similar slope. However, the relative fraction of individual components and the position of the break-in-slope might vary mostly depending on erupted mass and plume height.

10. Particle sedimentation at different distances from the vent can be described by a Gaussian distribution of terminal velocity with a mode that mostly depends on plume height and particle density. Nonetheless, we have observed a shift between high-density clasts and variable size-dependent density clasts at a same outcrop, mainly due to preferential breakage of coarse vesicular pumices at impact with the ground. We conclude that TGSDs derived from tephra deposits rich in highly vesicular juvenile material can be biased towards fine fractions generated during deposition in relation to the physical and textural features of the clasts (vesicularity, thermal history, density).

Acknowledgments C. Bonadonna was supported by the Swiss National Science Foundation (SNSF; No. 200020_125024). M. Pistolesi and R. Cioni were supported by the Italian Ministero Universita' e Ricerca funds (PRIN 2008-AshErupt project. The authors are grateful to A. Bertagnini, R. Gonzales, L. Francalanci, and P. Sruoga for their assistance in the field and to L. Dominguez for her help in grain size analyses. Many thanks also to A. Costa, L. Pioli, and L. Connor for constructive discussion. Both V. Manville (associate editor) and U. Kueppers are thanked for thorough review. 


\section{Appendix 1}

Isomass maps of individual $\phi$ categories for unit I (cumulative A to F layers) in kilogram per square meter
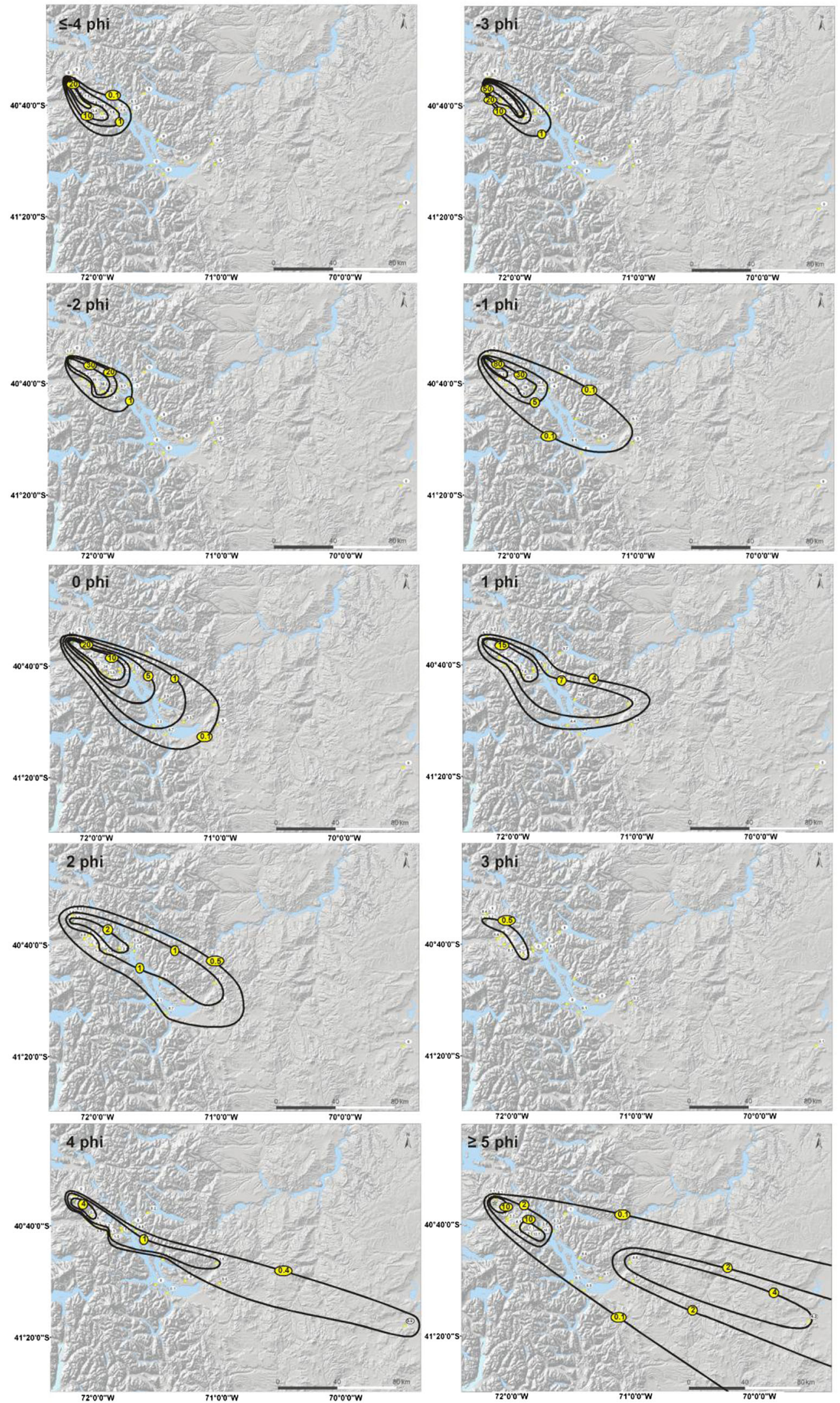


\section{Appendix 2}

\section{Calculation of particle terminal velocity}

Particle terminal velocity was calculated with the equation of Ganser (1993) for the mean diameter within each half- $\phi$ size bin (assuming a Gaussian size distribution within each size bin) and averaged over sedimentation height ( 1 to
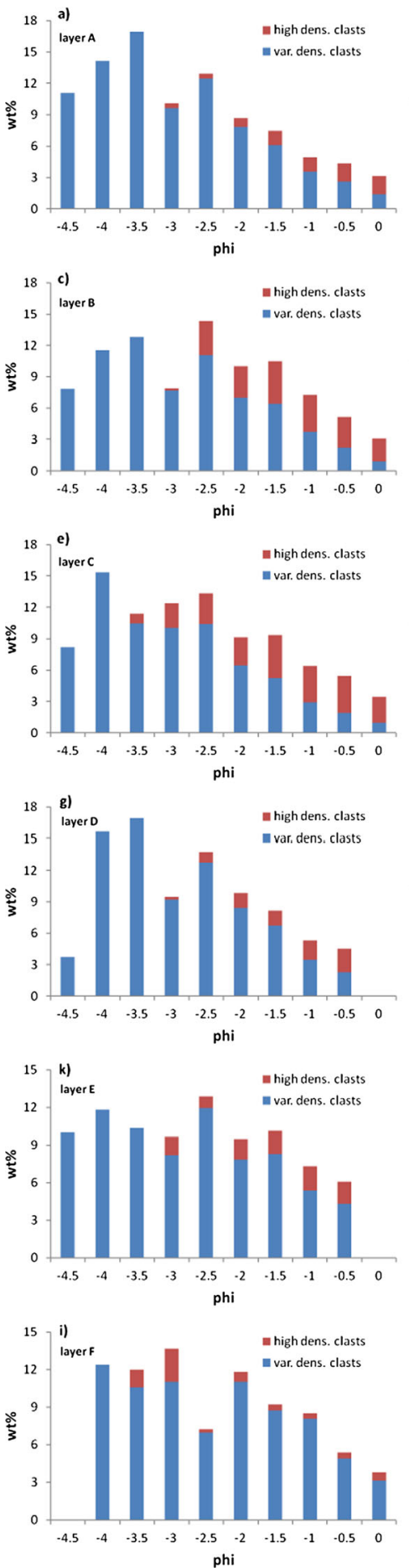

$14 \mathrm{~km}$ a.s.l. for $\mathrm{A}-\mathrm{F}, 1$ to $12 \mathrm{~km}$ a.s.l. for $\mathrm{H}$, and 1 to $10 \mathrm{~km}$ a.s.l. for $\mathrm{K} 2$; maximum plume heights were considered for all phases). Sphericity was kept at 0.9 for both clast categories (e.g., Folch 2012). Particle density was measured for individual clast sizes by Pistolesi et al. (2015) (see Fig. 9b, e, h). In Fig. 11, we show results for individual layers $\mathrm{A}$ to $\mathrm{F}$.
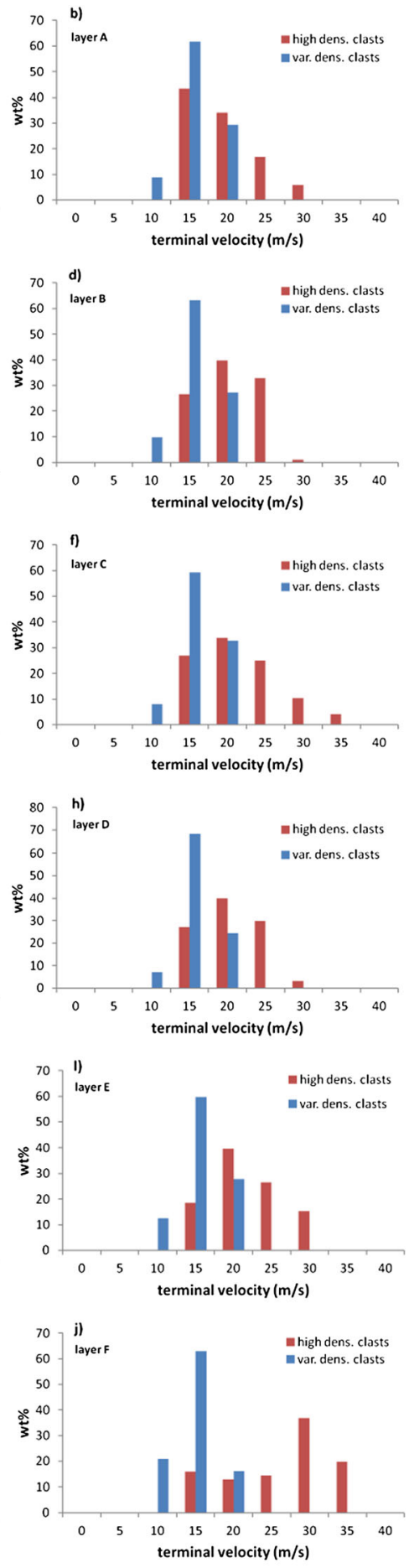

Fig. 11 Componentry (left column) and terminal velocity (right column) of tephra clasts ranging from 0 to $-4.5 \phi$ (i.e., $1-22.6 \mathrm{~mm}$ ) for layers A to F at a locality about $15 \mathrm{~km}$ from vent on the dispersal axis for unit I. See also Fig. 9 for results of the other layers 


\section{Appendix 3}

Calculation of the total grain-size distribution of unit I

In order to account for the missing distal data in the derivation of the total grain size distribution of the A-F cumulative layer (i.e., unit I), we have derived the mass/area of six points about $600 \mathrm{~km}$ from vent from the isopach maps com- piled soon after the eruption by Gáitan et al. (2011) and the . Based on these two maps that also describe the distal deposit, we assigned to the six distal data a thickness of $0.1 \mathrm{~cm}$ (i.e., $0.8 \mathrm{~kg} \mathrm{~m}^{-2}$ based on our most distal value of deposit density, i.e., $834 \mathrm{~kg} \mathrm{~m}^{-3}$; Fig. 5) and the grain size shown in Fig. 12. The two maps (based on dataset 1 and 2) are compared in Fig. 13.

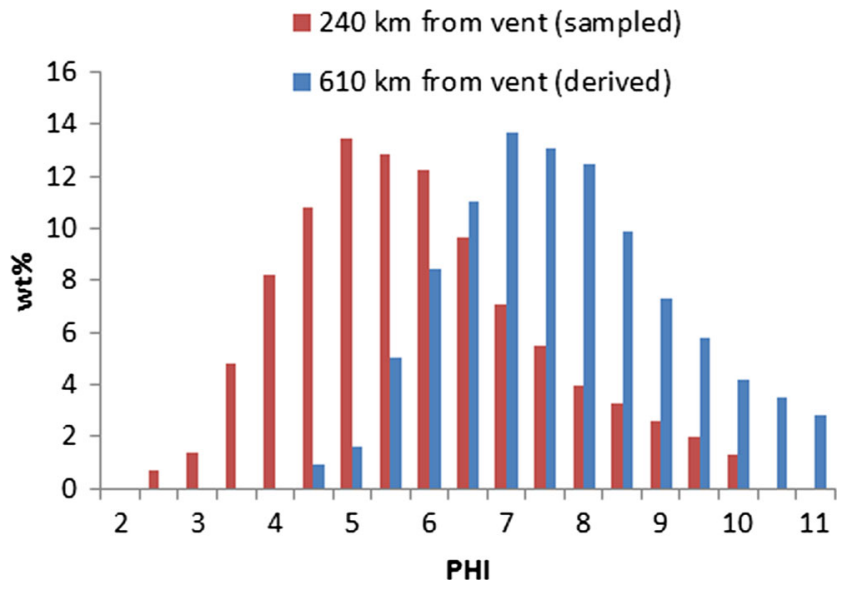

Fig. 12 Grain size distribution derived for the distal points $(610 \mathrm{~km}$ from vent; blue histograms) based on the distribution of our most distal sample at $240 \mathrm{~km}$ from vent (red histograms) and on the proportion of lapilli, coarse ash, and fine ash as derived from the best-fit equations in Fig. 3a, main text (i.e., Gaussian distribution with mode of $7 \phi$ and composed of $99 \%$ fine ash)

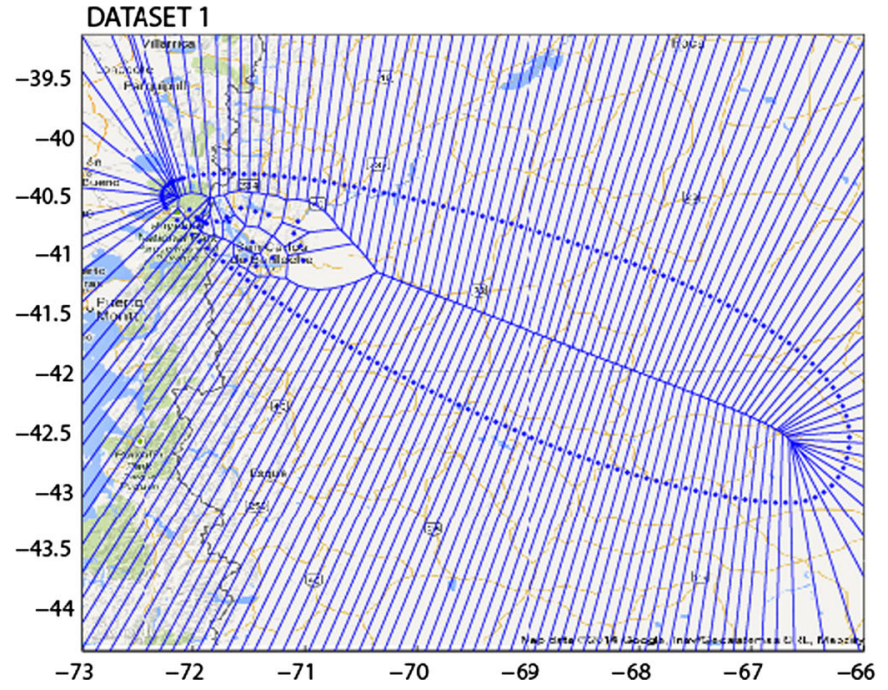

Fig. 13 Maps showing the Voronoi triangulation and the zero line used for the determination of the total grain size distribution based on the Voronoi tessellation method of Bonadonna and Houghton (2005) and using the application of Biass and Bonadonna (2014) for: a dataset 1

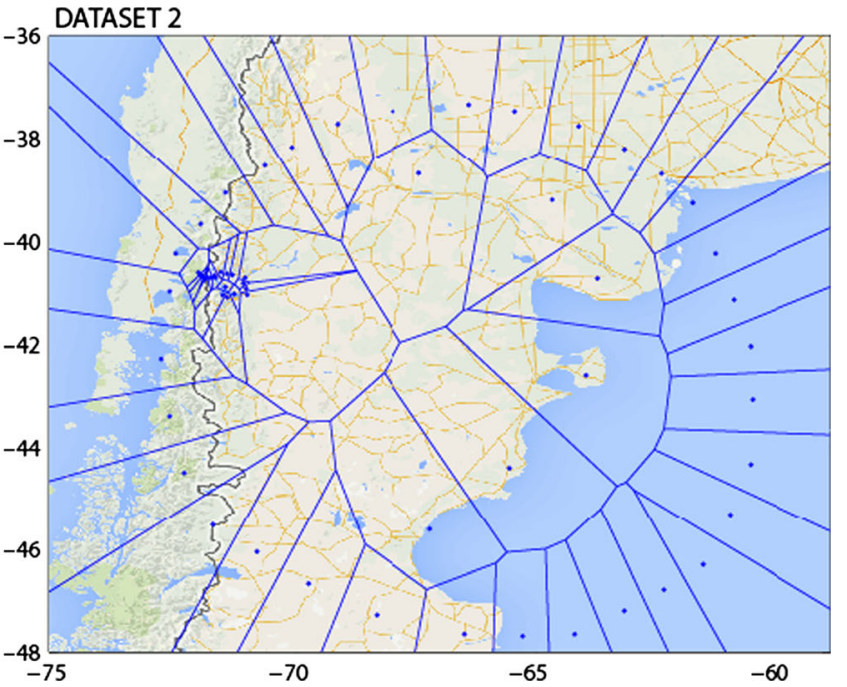

(i.e., samples collected in our field surveys) and b dataset 2 (dataset 1 combined with six distal points derived from the isopach maps compiled soon after the eruption by Gaitán et al. (2011) and the INTA (2011)) 


\section{Appendix 4}

Inversion on grain size using the model TEPHRA2
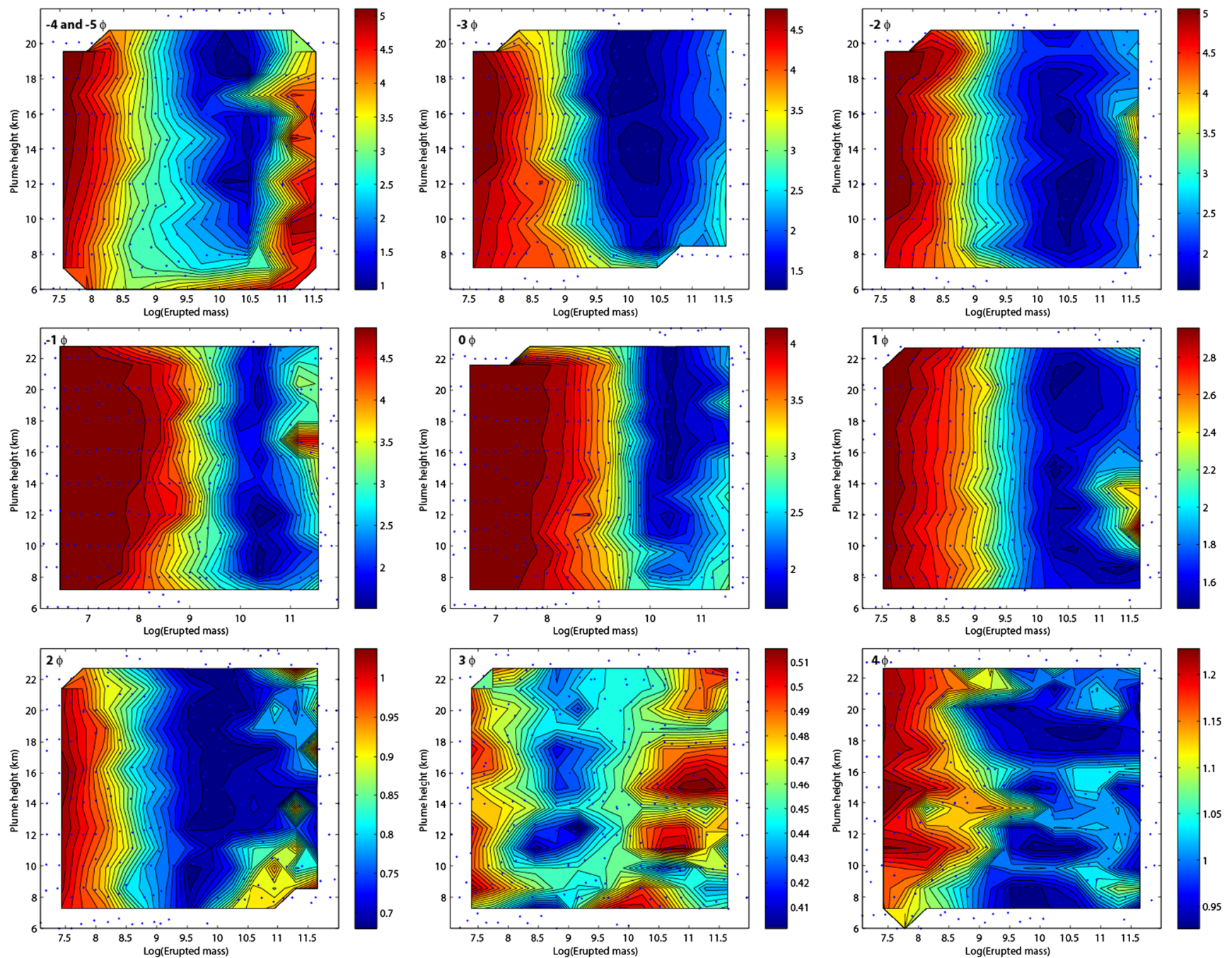

Fig. 14 Plot of Log(erupted mass) vs. plume height $(\mathrm{km})$ (above sea level) showing the minimum values (dark blue) of the goodness-of-fit measure (root mean square error, RMSE) associated with individual $\phi$

size categories (indicated in each plot) of the climactic phase of Córdon

Caulle eruption (i.e., unit I)

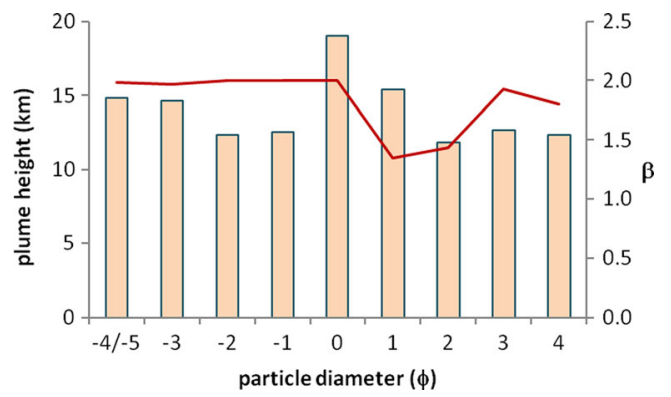

Fig. 15 Best-fit plume height above sea level as derived from inversion on individual grain size categories (average value $=13.9 \mathrm{~km}$ ). The mass along the eruptive plume in the model TEPHRA2 is described by a beta function characterized by two parameters, $\alpha$ and $\beta$ (Connor et al. 2015, in press). For simplicity, in these inversion calculations, $\alpha$ is kept constant (i.e., 3 ) and $\beta$ is left vary between 0.5 (i.e., particles are mostly released at the top of the cloud) and 2 (i.e., particles are released at a height which is $60-70 \%$ the total height). Average best-fit value for the climactic phase of Córdon Caulle eruption is 1.8 (i.e., particles are mostly released at a height which is $70 \%$ the total height) 


\section{References}

Alfano F, Bonadonna C, Connor CB, Volentik A (submitted) From tephra grain-size and dispersal to magma fragmentation: the case of the 2008 Chaitén rhyolitic eruption, Chile. Bull Volcanol

Alfano F, Bonadonna C, Gurioli L (2012) Insights into eruption dynamics from textural analysis: the case of the May, 2008, Chaiten eruption. Bull Volcanol 74(9):2095-2108

Biass S, Bonadonna C (2014) TOTGS: Total grainsize distribution of tephra fallout https://vhub.org/resources/3297 Accessed 26 Jan 2015

Bonadonna C, Costa A (2012) Estimating the volume of tephra deposits: a new simple strategy. Geology 40(5):415-418

Bonadonna C, Houghton BF (2005) Total grainsize distribution and volume of tephra-fall deposits. Bull Volcanol 67:441-456

Bonadonna C, Mayberry GC, Calder ES et al (2002) Tephra fallout in the eruption of Soufrière Hills Volcano, Montserrat. In: Druitt TH, Kokelaar BP (eds) The eruption of Soufrière Hills Volcano, Montserrat, from 1995 to 1999. Geological Society, London, Memoir, pp 483-516

Bonadonna C, Phillips JC, Houghton BF (2005) Modeling tephra sedimentation from a Ruapehu weak plume eruption. Journal of Geophysical Research 110(B8, B08209)

Bonadonna C, Genco R, Gouhier M, et al (2011) Tephra sedimentation during the 2010 Eyjafjallajokull eruption (Iceland) from deposit, radar, and satellite observations. J Geophys Res Solid Earth 116

Bonadonna C, Cioni R, Pistolesi M, et al (2013) Determination of the largest clast sizes of tephra deposits for the characterization of explosive eruptions: a study of the IAVCEI commission on tephra hazard modelling. Bull Volcanol 75(1)

Bonadonna C, Pistolesi M, Cioni R, et al. (2015, in press) Dynamics of wind-affected volcanic plumes: the example of the 2011 Cordón Caulle eruption, Chile. J Geophys Res

Brazier S, Sparks RSJ, Carey SN et al (1983) Bimodal grain-size distribution and secondary thickening in air-fall ash layers. Nature 301(5896):115-119

Brown RJ, Bonadonna C, Durant AJ (2012) A review of volcanic ash aggregation. Phys Chem Earth 45-46:65-78

Carazzo G, Jellinek AM (2012) A new view of the dynamics, stability and longevity of volcanic clouds. Earth Planet Sci Lett 325:39-51

Carazzo G, Jellinek AM (2013) Particle sedimentation and diffusive convection in volcanic ash-clouds. J Geophys Res Solid Earth Planets 118(4):1420-1437

Carey SN, Sigurdsson H (1982) Influence of particle aggregation on deposition of distal tephra from the May 18, 1980, eruption of Mount St-Helens volcano. J Geophys Res 87(B8):7061-7072

Castro JM, Schipper CI, Mueller SP, et al. (2013) Storage and eruption of near-liquidus rhyolite magma at Cordon Caulle, Chile. Bull Volcanol 75(4)

Collini E, Osores SM, Folch A et al (2013) Volcanic ash forecast during the June 2011 Cordon Caulle eruption. Nat Hazards 66(2):389-412

Connor CB, Connor LJ, Bonadonna C, Luhr JF, Savov IP, NavarroOchoa C (2015, in press) Modeling tephra thickness and particle size distribution of the 1913 eruption of Volcan de Colima, Mexico. In: Varley N, Komorowski JC (eds) Volcan de Colimamanaging the threat. Springer Verlag for the IAVCEI in the Active Volcanoes of the World Series

Dingwell DB, Lavallee Y, Kueppers U (2012) Volcanic ash: a primary agent in the Earth system. Phys Chem Earth 45-46:2-4

Dufek J, Manga M, Patel A (2012) Granular disruption during explosive volcanic eruptions. Nat Geosci 5(8):561-564

Durant AJ, Rose WI (2009) Sedimentological constraints on hydrometeor-enhanced particle deposition: 1992 eruptions of Crater Peak, Alaska. J Volcanol Geotherm Res 186(1-2):40-59
Durant AJ, Rose WI, Sarna-Wojcicki AM, et al. (2009) Hydrometeorenhanced tephra sedimentation: constraints from the 18 May 1980 eruption of Mount St. Helens. J Geophys Res Solid Earth 114

Durant AJ, Villarosa G, Rose WI et al (2012) Long-range volcanic ash transport and fallout during the 2008 eruption of Chaiten volcano, Chile. Phys Chem Earth 45-46:50-64

Eychenne J, Le Pennec J-L, Troncoso L et al (2012) Causes and consequences of bimodal grain-size distribution of tephra fall deposited during the August 2006 Tungurahua eruption (Ecuador). Bull Volcanol 74(1):187-205

Fisher RV, Schmincke HU (1984) Pyroclastic rocks. pp xiv +472 pp-xiv+ $472 \mathrm{pp}$

Folch A (2012) A review of tephra transport and dispersal models: evolution, current status, and future perspectives. J Volcanol Geotherm Res 235:96-115

Folch A, Mingari L, Osores MS, Collini E (2014) Modeling volcanic ash resuspension - application to the 14-18 October 2011 outbreak episode in central Patagonia, Argentina. Nat Hazards Earth Syst Sci 14(1):119-133

Fontijn K, Ernst GGJ, Bonadonna C et al (2011) The 4-ka Rungwe Pumice (South-Western Tanzania): a wind-still Plinian eruption. Bull Volcanol 73(9):1353-1368

Gaitán JJ, Ayesa JA, Umaña F, Raffo F, Bran DB (2011) Cartografía del área afectada por cenizas volcánicas en las provincias de Río Negro y Neuquén. In: INTA http://inta.gob.ar/documentos/cartografia-delarea-afectada-por-cenizas-volcanicas-en-las-provincias-de-rionegro-y-neuquen/

Ganser GH (1993) A rational approach to drag prediction of spherical and nonspherical particles. Powder Technol 77(2):143-152

Hadley D, Hufford GL, Simpson JJ (2004) Resuspension of relic volcanic ash and dust from Katmai: still an aviation hazard. Weather Forecast 19(5):829-840

Hildreth W, Drake RE (1992) Volcano Quizapu, Chilean Andes. Bull Volcanol 54:93-125

Hincks TK, Aspinall WP, Baxter PJ et al (2006) Long term exposure to respirable volcanic ash on Montserrat: a time series simulation. Bull Volcanol 68(3):266-284

Hobbs PV, Hegg DA, Radke LF (1983) Resuspension of volcanic ash from Mount St-Helens. J Geophys Res Oceans Atmos 88(NC6): 3919-3921

Inman DL (1952) Measures for describing the size distribution of sediments. J Sediment Petrol 22:125-145

INTA (2011), Estado de situación derivado de las cenizas del complejo volcánico Puyehue -Cordón caulle en la provincia del Chubut Rep., INTA http://inta.gob.ar/documentos/cartografia-del-area-afectadapor-cenizas-volcanicas-en-las-provincias-de-rio-negro-y-neuquen Accessed 26 Jan 2015

Kaminski E, Jaupart C (1998) The size distribution of pyroclasts and the fragmentation sequence in explosive volcanic eruptions. J Geophys Res Solid Earth 103(B12):29759-29779

Kueppers U, Scheu B, Spieler O, Dingwell DB (2006) Fragmentation efficiency of explosive volcanic eruptions: a study of experimentally generated pyroclasts. J Volcanol Geotherm Res 153(1-2):125-135

Leadbetter SJ, Hort MC, von Lowis S, et al. (2012) Modeling the resuspension of ash deposited during the eruption of Eyjafjallajokull in spring 2010. J Geophys Res Atmos 117

Legros F (2000) Minimum volume of a tephra fallout deposit estimated from a single isopach. J Volcanol Geotherm Res 96:25-32

Manzella I, Bonadonna C, Phillips JC, Monnard H (2015) The role of convective instabilities in deposition of volcanic ash. Geology. doi: 10.1130/G36252.1

Mastin LG, Bonadonna C, Folch A, Webley P, stunder B, Pavolonis M (2013) "Eruption data for ash-cloud model validation," https://vhub. org/resources/2431 Accessed 26 Jan 2015 
Murrow PJ, Rose WI, Self S (1980) Determination of the total grain-size distribution in a vulcanian eruption column, and its implications to stratospheric aerosol perturbation. Geophys Res Lett 7(11):893-896

Perugini D, Speziali A, Caricchi L, Kueppers U (2011) Application of fractal fragmentation theory to natural pyroclastic deposits: Insights into volcanic explosivity of the Valentano scoria cone (Italy). J Volcanol Geotherm Res 202(3-4):200-210

Pistolesi M, Cioni R, Bonadonna C, et al (2015) Complex dynamics of small-moderate volcanic events: the example of the 2011 rhyolitic Cordón Caulle eruption, Chile. Bull Volcanol. doi:10.1007/s00445014-0898-3

Prata AJ, Grant IF (2001) Retrieval of microphysical and morphological properties of volcanic ash plumes from satellite data: application to Mt Ruapehu, New Zealand. Q J R Meteorol Soc 127(576):21532179

Pyle DM (1989) The thickness, volume and grainsize of tephra fall deposits. Bull Volcanol 51(1):1-15

Rose WI, Self S, Murrow PJ, et al. (2007) Nature and significance of small volume fall deposits at composite volcanoes: insights from the October 14, 1974 Fuego eruption, Guatemala. Bull Volcanol

Rust AC, Cashman KV (2011) Permeability controls on expansion and size distributions of pyroclasts. J Geophys Res Solid Earth 116

Scasso R, Corbella H, Tiberi P (1994) Sedimentological analysis of the tephra from 12-15 August 1991 eruption of Hudson Volcano. Bull Volcanol 56:121-132

Schipper CI, Castro JM, Tuffen H, James MR, How P (2013) Shallow vent architecture during hybrid explosive-effusive activity at Cordón Caulle (Chile, 2011-12): evidence from direct observations and pyroclast textures. J Volcanol Geoth Res 262:25-37. doi:10.1016/ j.jvolgeores.2013.06.005

Scollo S, Del Carlo P, Coltelli M (2007) Tephra fallout of 2001 Etna flank eruption: analysis of the deposit and plume dispersion. J Volcanol Geotherm Res 160(1-2):147-164

SERNAGEOMIN/OVDAS (2011) Puyehue - Cordón Caulle: Reporte especial de actividad volcánica No31. In: http://www.sernageomin. $\mathrm{cl} /$ volcan.php?pagina $=7 \&$ iId $=38$
Sparks RSJ, Wilson L, Sigurdsson H (1981) The pyroclastic deposits of the 1875 eruption of Askja, Iceland. Philos Trans R Soc Lond 229: 241-273

Thorsteinsson T, Johannsson T, Stohl A, Kristiansen NI (2012) High levels of particulate matter in Iceland due to direct ash emissions by the Eyjafjallajokull eruption and resuspension of deposited ash. $\mathbf{J}$ Geophys Res Solid Earth 117

Varekamp JC, Luhr JF, Prestegaard KL (1984) The 1982 eruptions of ElChichon Volcano (Chiapas, Mexico) - character of the eruptions, ashfall deposits, and gas-phase. J Volcanol Geotherm Res 23(1-2):39-68

Volentik ACM, Bonadonna C, Connor CB et al (2010) Modeling tephra dispersal in absence of wind: insights from the climactic phase of the 2450 BP Plinian eruption of Pululagua volcano (Ecuador). J Volcanol Geotherm Res 193(1-2):117-136

Waitt RB, Jr., Hansen VL, Sarna-Wojcicki AM, Wood SH (1981) Proximal air-fall deposits of eruptions between May 24 and August 7, 1980-stratigraphy and field sedimentology Mount St. Helens. In: Lipman PW, Mullineaux DR (eds) The 1980 eruptions of Mount St. Helens, Washington. U.S. Geological Survey Professional Paper Washington, D.C., pp 617-628

Walker GPL (1981) Characteristics of two phreatoplinian ashes, and their water-flushed origin. J Volcanol Geotherm Res 9:395-407

Wiesner MG, Wetzel A, Catane SG et al (2004) Grain size, areal thickness distribution and controls on sedimentation of the 1991 Mount Pinatubo tephra layer in the South China Sea. Bull Volcanol 66(3): 226-242

Wilson TM, Cole JW, Stewart C et al (2011) Ash storms: impacts of wind-remobilised volcanic ash on rural communities and agriculture following the 1991 Hudson eruption, southern Patagonia, Chile. Bull Volcanol 73(3):223-239

Wilson TM, Stewart C, Bickerton H, et al. (2013) Impacts of the June 2011 Puyehue-Cordon Caulle volcanic complex eruption on urban infrastucture, agricolture and public health. In: GNS Science Report 2012/20.

Wohletz KH, Sheridan MF, Brown WK (1989) Particle-size distributions and the sequential fragmentation/transport theory applied to volcanic ash. J Geophys Res Solid Earth Planets 94(B11):15703-15721 